Portland State University

PDXScholar

Civil and Environmental Engineering Master's

Project Reports

Spring 2014

\title{
Modelling Rainwater-Harvesting System Reliability Based on Historical Precipitation Data for Portland
}

Mrinali Mathur

Portland State University

Follow this and additional works at: https://pdxscholar.library.pdx.edu/cengin_gradprojects

Part of the Civil and Environmental Engineering Commons, and the Water Resource Management Commons

Let us know how access to this document benefits you.

\section{Recommended Citation}

Mathur, Mrinali, "Modelling Rainwater-Harvesting System Reliability Based on Historical Precipitation Data for Portland" (2014). Civil and Environmental Engineering Master's Project Reports. 11. https://doi.org/10.15760/CEEMP.33

This Project is brought to you for free and open access. It has been accepted for inclusion in Civil and Environmental Engineering Master's Project Reports by an authorized administrator of PDXScholar. Please contact us if we can make this document more accessible: pdxscholar@pdx.edu. 
Modelling rainwater-harvesting system reliability based on historical precipitation data for Portland

BY

MRINALI MATHUR

A research project report submitted in partial fulfillment

of the requirement for the degree of

\section{MASTER OF SCIENCE}

IN

CIVIL AND ENVIRONMENTAL ENGINEERING

Project Advisor:

Dr. Bill Fish

Portland State University

2013 


\section{ABSTRACT}

Rainwater harvesting can ease the water availability problems for many parts of the world where water is not easily available. It is also a solution for minimizing stormwater runoff and better managing sewers by preventing combined sewers to overflow. The goal of this project is to calculate the reliability of rainwater harvesting systems and provide optimum size of the storage tank using historical records for Portland specific rain pattern. A simple water balance approach for historical data is used to calculate the reliability by which rainwater harvesting system can be used as a means of irrigating gardens in Portland. The size of the storage units needs to be adequate with the area of the roof and the desired water use rate. The maximum storage required to attain $100 \%$ reliability is more than $20 \mathrm{~m}^{3}$ for lower end of irrigation demand and more than $100 \mathrm{~m}^{3}$ for upper end of the irrigation demand for specific catchment area. The reliability with which Portland backyard gardens can be irrigated is approximately $20 \%-50 \%$, with lower end of range representing $1 \mathrm{~m} 3$ storage and the upper end of range representing $5 \mathrm{~m}^{3}$ of storage tank. Roof top runoff inputs to the combined sewer system are reduced by approximately $15 \%$ and potable water saved is $38 \%$ with storage tank volume of $5 \mathrm{~m}^{3}$. A cost benefit analysis suggest that for a tank of $5 \mathrm{~m} 3$ it takes 15 years to recover the investment done for installing rainwater harvesting system. 


\section{ACKNOWLEDGEMENT}

I thank my advisor, Dr. Bill Fish, for his valuable guidance, extraordinary support, inspiration, and encouragement. This project would never have been conceptualized without the ideas and motivation that he provided me. I greatly appreciate his patience and the trust he showed in me throughout my project. He was always there to support me both morally and academically whenever I was in a fix. My gratitude for him cannot be expressed in a paragraph.

I will also like to thank my best friend and husband Rachit for his support, encouragement and unconditional love throughout this project. I also want to express my gratitude to my entire family for all their love and encouragement which served as a source of inspiration throughout this project.

My gratitude is to the Department of Civil and Engineering's staff, especially Megan Niermeyer who have always been available to help and answer questions. 


\section{Table of Contents}

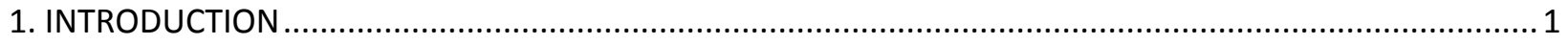

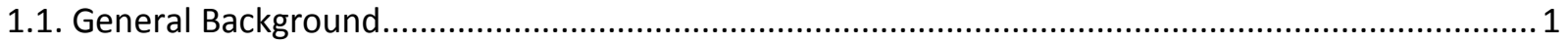

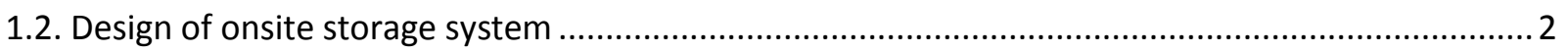

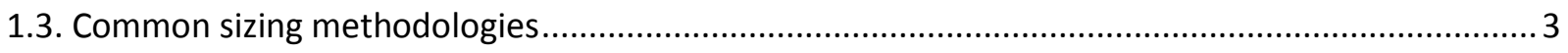

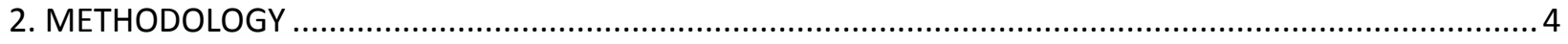

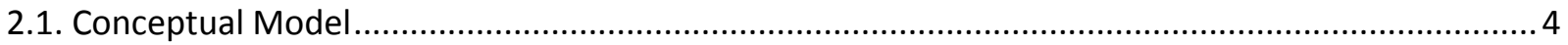

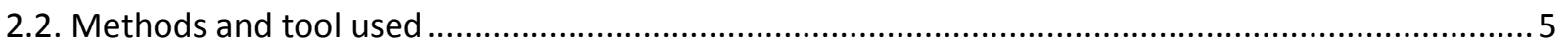

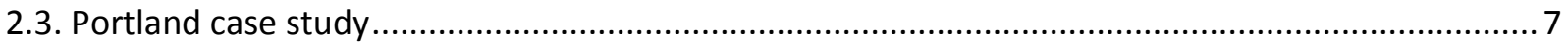

2.4. Selection of Model parameters ….......................................................................................... 10

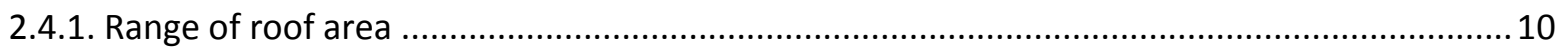

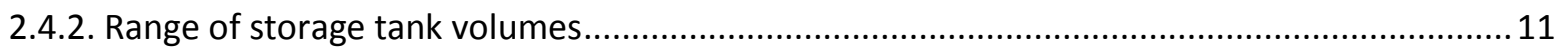

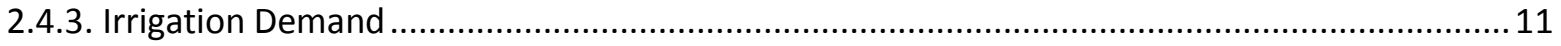

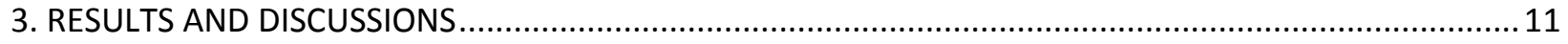

3.1. Maximum storage required $(\mathrm{m} 3)$ for desired reliability ............................................................ 11

3.2. Rain water harvesting system performance (Reliability) ............................................................. 14

3.3. Volume of water required from city ...................................................................................... 17

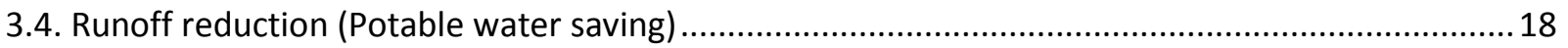

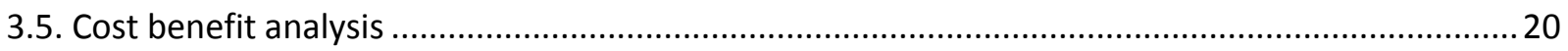

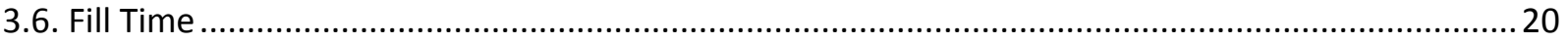

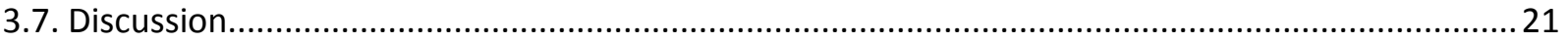

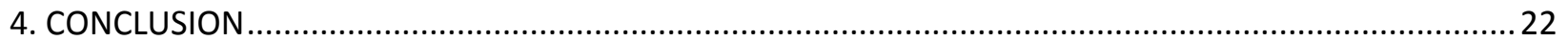

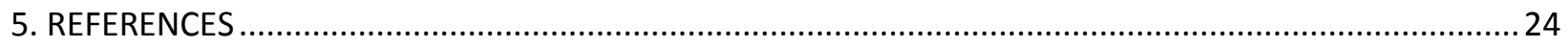

Appendix A …

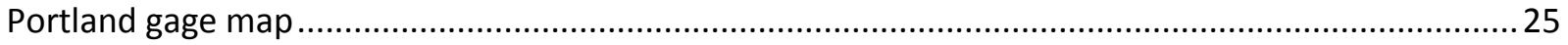




\section{List of Figures}

Figure 1. Chultun Mayan stucco cement/lime plastered underground tank and ground catchment system, Mexico.

Figure 2. Conceptual model of tank to calculate storage volume ........................................................ 4

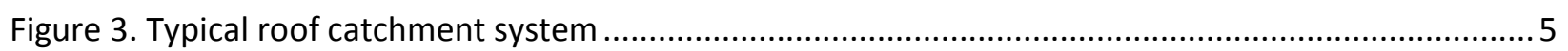

Figure 4. Schematic diagram of the Shortage and Reliability Estimation Tool (SARET) (M. Basinger et., al)

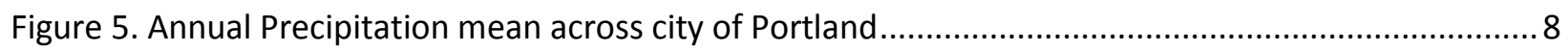

Figure 6. Histogram of daily precipitation amounts (1999-2013) ......................................................... 9

Figure 7. Box and Whisker plot depicting variability in monthly precipitation in Portland. The bottoms of the Whisker depict the lowest monthly value within 1.5 IQR of the lower quartile, and the highest Whiskers depict monthly values within 1.5 IQR of the upper....

Figure. 8. Month wise distribution of precipitation (inches) from May - October (Summer Months) from 1999-2013

Figure.9. Plot Irrigation demand ( $\mathrm{cm} / 7$ days) versus storage volume $\left(\mathrm{m}^{3}\right)$ to achieve desired reliability when we run model for all 15 years. Irrigation area $=100 \mathrm{~m}^{2}$ and catchment area $=250 \mathrm{~m}^{2} \ldots \ldots \ldots \ldots \ldots \ldots . . . . . .12$

Figure.10. A zoomed look at figure 9.

Figure.11. Plot Irrigation demand ( $\mathrm{cm} / 7$ days) versus storage volume $\left(\mathrm{m}^{3}\right)$ to achieve desired reliability $\left(20^{\text {th }}\right.$ percentile) when we run model for all 15 years. Irrigation area $=100 \mathrm{~m}^{2}$ and catchment area $=$ $250 \mathrm{~m}^{2}$......

Figure.12. Plot Irrigation demand (cm/7days) versus storage volume $(\mathrm{m} 3)$ to achieve desired reliability (80th percentile) when we run model for all 15 years. Irrigation area $=100 \mathrm{~m} 2$ and catchment area= $250 \mathrm{~m} 2$

Figure.13. Percent reliability each year when $S \max =5 \mathrm{~m} 3$, catchment area $=250 \mathrm{~m} 3$ and irrigation demand $4 \mathrm{~m}^{3} / 7$ days.

Figure.14. Percent reliability each year when $S \mathrm{max}=10 \mathrm{~m} 3$, catchment area $=250 \mathrm{~m} 3$ and irrigation demand $4 \mathrm{~m}^{3} / 7$ days.

Figure.15. Storage volume available in summer months for $S \max =5 \mathrm{~m}^{3}$, catchment area $=250 \mathrm{~m}^{2}$ and Irrigation demand $=4 \mathrm{~m}^{3}$ per 7 days

Figure.16. Storage volume available in summer months for Smax $=10 \mathrm{~m}^{3}$, catchment area $=250 \mathrm{~m}^{2}$ and Irrigation demand $=4 \mathrm{~m}^{3}$ per 7 days

Figure.17. Volume of water required from municipality (month wise) in addition to water from rain water harvesting system with Smax $=5 \mathrm{~m} 3$, catchment area $=250 \mathrm{~m}^{3}$ and Irrigation demand is $4 \mathrm{~m}^{3}$ per 7 days for last 15 years.

Figure.18. Volume of water required from municipality (month wise) in addition to water from rain water harvesting system with $S \max =10 \mathrm{~m}^{3}$, catchment area $=250 \mathrm{~m}^{2}$ and Irrigation demand is $4 \mathrm{~m}^{3}$ per 7 days for last 15 years.

Figure.19. Runoff/potable water saved $\left(\mathrm{m}^{3}\right)$ each year by using rain water harvesting system with $\mathrm{Smax}=$ $5 \mathrm{~m}^{3}$, irrigation demand $4 \mathrm{~m}^{3}$ per 7 days and catchment area $=250 \mathrm{~m}^{2}$.

Figure.20. Runoff/potable water saved $\left(\mathrm{m}^{3}\right)$ each year by using rain water harvesting system with $\mathrm{Smax}=$ $10 \mathrm{~m}^{3}$, irrigation demand $4 \mathrm{~m}^{3}$ per 7 days and catchment area $=250 \mathrm{~m}^{2}$ 
Figure. 21. Time required to fill the srorage volume from precipitation (days)....................................20

Figure. 22. Reliability contour for irrigation demand $4 \mathrm{~m}^{3} / 7$ days (May-October) ....................................2 21

Figure. 23. Reliability contour for irrigation demand $4 \mathrm{~m}^{3} / 7$ days (May-October) ................................... 22 


\section{INTRODUCTION}

\subsection{General Background}

Water conservation is an important focus in many parts of the world because of the scarcity in availability of water. Rainwater harvesting can ease this problem, rainwater usage has been recognized to promote significant potable water savings in buildings. The purpose of harvested water varies. In countries like Kenya rainwater is the only source of domestic water supply. And in Countries like Germany the cost of water treatment is increased due to ground water contamination so rain water is of great use.

Rainwater harvesting is an ancient practice. The roots of rain water harvesting go deep in history. Evidences suggest use of simple stone structure in Baluchistan for irrigation purposes around third century B.C. (Agarwal and Narain 1997). Rainwater harvesting cisterns were used in ancient Greek (Phoca \& valantis, 1999) cited in Basinger et.,al 2010, Israel( Evenari et al., 1961), Mediterranean region (Hasse, 1989), India (Radhakrishna, 2003) and many other places. Figure 1 represents Mayan stucco cement/lime- plastered underground tank and ground catchment system in limestone region, Yucatan Peninsula, Mexico known as Chultun.

At present largest rooftop rainwater harvesting projects are going on in some parts of china and Brazil. Harvested water is being used for providing drinking water, domestic water, water for livestock, water for small irrigation and a way to replenish ground water levels. Rainwater harvesting (RWH) refers to collecting, storing and reusing rain water in situ. Installation of RWH is compulsory for many parts of the world like in India \& USA.

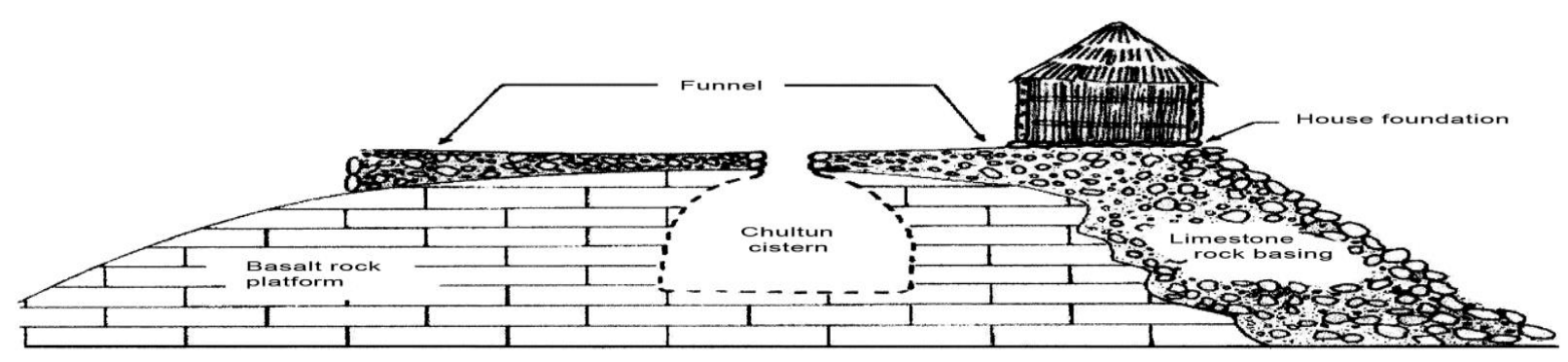

Figure 1. Chultun- Mayan stucco cement/lime plastered underground tank and ground catchment system, Mexico. 
In Portland plenty of rain falls from late fall to spring. Storing water in these periods is helpful not only in meeting summertime demand but also in reducing the rate and volume of storm water flow to collection systems. Efforts are being made by City of Portland to conserve water and build green infrastructure. With the increasing impervious area resulting in increasing runoff the city is facing challenges to manage the storm water runoff and preventing combined sewer overflows or flooding of the streams. To conserve water and to manage storm runoff onsite, conservation techniques like rain barrel and underground cisterns are often encouraged.

There has been research conducted in most parts of the world. These researches are very much specific to the rainfall pattern and amount. But there has been not much specific to Portland rain pattern. The goal of this research project is to perform quantitative mass balance and statistical data analysis of the Portland precipitation pattern and to determine the reliability of Rainwater harvesting system for given storage, catchment area and demand. Optimum tank sizing, potable water saving and runoff reduction are also investigated. It will help people to make educated decision about the storage volume size they need to install in their houses to get maximum return on their investment.

\subsection{Design of onsite storage system}

The required capacity of storage unit is a function of rooftop surface area/catchment area, demand (irrigation area, toilet flushing and more), precipitation amount and pattern. The quality of storage unit can be improved by using first flush diversion which means to divert the first rainfall away after given number of days. The common parameters that play important role in deciding the size of storage tank are cost constraints, available space to install RWH system and aesthetic aspects. Cost plays a major role in deciding the size of RWH system. A 250 gallon $\left(0.946 \mathrm{~m}^{3}\right)$ rain barrel approximately costs 200 dollars assembled. We need to weight how much money to invest to get a good return of investment based on savings in utility bills. We also need to consider the availability of the space where we are planning to place the RWH system if the required space is available or not at the same time it should be aesthetically pleasing as most of these are placed in backyard of the house. The common rain barrels are available in $50-250$ gallons range and cisterns are available in $200-10,000$ gallons range. A full 55 gallon rain barrel weighs over 400 lbs. 


\subsection{Common sizing methodologies}

Rain water harvesting system can be sized considering only variability in annual precipitation amounts like Gould and Nissen Peterson (1999) published catchment versus storage curve with varying average annual rainfall. The demand is assumed to be $100 \mathrm{l} /$ day and these graphs provide "degree of security" for which different tank size can be estimated. The temporal and /seasonal distribution is not taken in account. Some of the techniques for sizing RWH system are Dry season demand versus supply, graphical methods, mass curve analysis, statistical methods and computer based methods.

One simple approach for sizing is to continuously do mass balance using historical precipitation observation and defined demand. Ghisi et.al used this approach to show that the average potential to save potable water is $41 \%$ ranging from $12 \%$ to $79 \%$ in some parts of Brazil.

The other approach is to generate stochastic precipitation observations. These observations can be parametric or non-parametric. Parametric rainfall models have some statistical relationship that are true for one location but may not be correct for another location because causes of rainfall vary from one place to other (Lall et al., 1996) cited by(Basinger, Montalto and Lall et al., 2010). "The non-parametric method use pdfs to describe rainfall occurrence (i.e. duration of wet and dry spells) but these are derived directly from local observations. Synthetic time series ensembles can then be constructed as a sequential progression of wet and dry spell states or as Markov chains of different order, with precipitation amounts resampled with replacement from the historical record (Lall et al., 1996)" cited by (Basinger, Montalto and Lall et al., 2010).

The performance of rain water harvesting systems can be expressed in either the volumetric reliability or the time based reliability (Mc. Mohan et al., 2006) cited by A.palla et al., 2011. The volumetric reliability also known as water saving efficiency is defined as the total volume of rain water supplied divided by total demand during the entire simulation period. The time based reliability requires taking into account the time steps when the demand is fully met. In time based reliability failure is considered when there is not enough water in the tank to meet the demand. The value can either be 0 (demand fully met) or 1 (demand not met). The volumetric reliability is less restrictive than time based because it takes into account the time step where the demand is partially met. For this study we will use volumetric reliability. 


\section{METHODOLOGY}

\subsection{Conceptual Model}

Figure 2 represents the conceptual model of the tank to calculate the storage volume at any time. We are considering simple tank model with a spill.

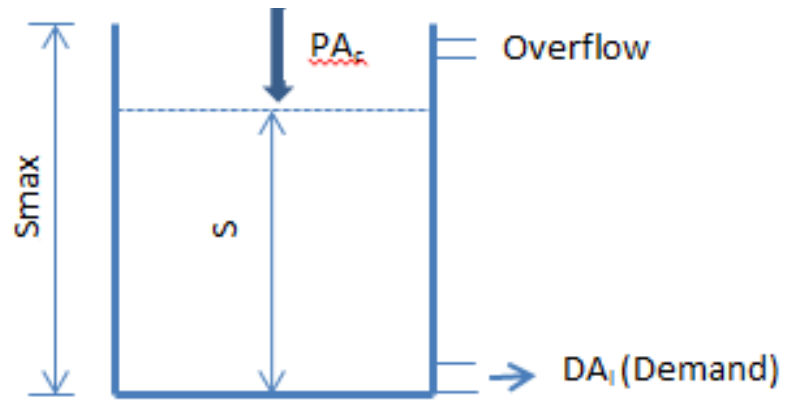

Figure 2. Conceptual model of tank to calculate storage volume

We used simple mass balance equations to calculate the volume of storage at any time. We are using the approach to release first and then fill. So $S_{i}$ will be an intermediate storage which cannot exceed Smax we will call it $\mathrm{S}^{\prime}$.

$S^{\prime}=S_{i-1}-D_{i} A_{l}+P_{i} A_{c}$

$S_{i}=0 \quad$ if $S^{\prime}<0$

$\mathrm{S}_{\mathrm{i}}=\mathrm{S}^{\prime} \quad$ if $0 \leq \mathrm{S}^{\prime} \leq \mathrm{Smax}$

$S_{i}=S \max \quad$ if $S^{\prime} \geq S \max$

Where $S_{i}=$ Volume of the water in storage at the end of the day " $\mathrm{i}$ ", $\mathrm{S}_{\mathrm{i}-1}=$ volume of the water in storage at the end of day "i-1", $A_{c}=$ Catchment area, $A_{1}=$ Irrigation area, $D_{i}=$ Demand per meter square area from tank on day "I", $P_{i}=$ Precipitation amount on day “ $i$ ", Smax= Volume of tank. Figure 3 represents a typical roof carchment system. 


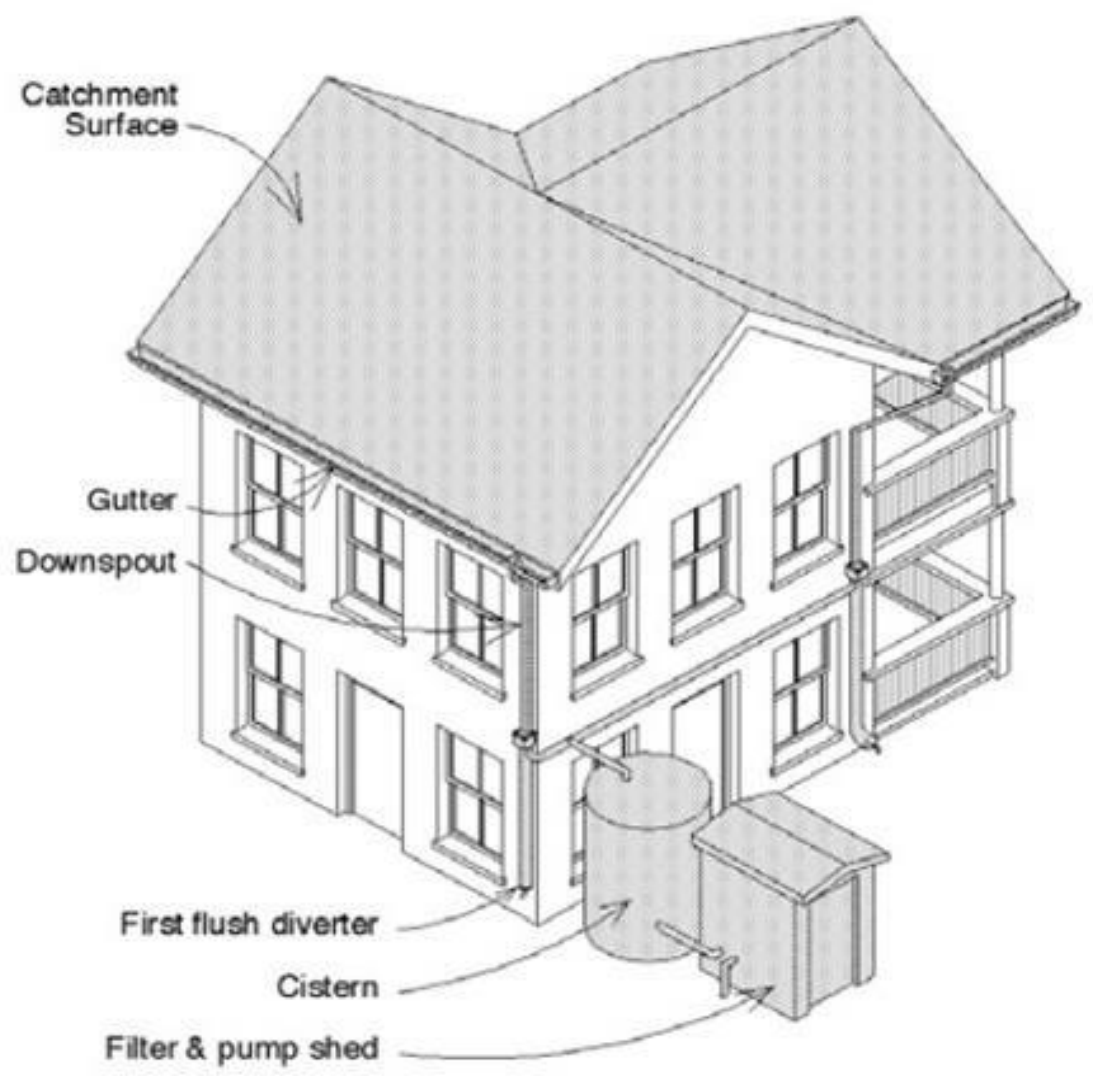

Figure 3. Typical roof catchment system

\subsection{Methods and tool used}

An important tool I used for this purpose is developed by Drexel University known as "Storage and Reliability Estimation Tool (SARET). This is based on non-parametric stochastic approach. A flow diagram of SARET is shown in figure 4.

The precipitation data is generated using user specified historical record of daily total precipitation observations. Firstly arrays are developed within historical record for each day characterizing each day as "wet" or "dry" (wet for precipitation and dry for no precipitation). The moving window technique is then used to develop the array consisting of daily precipitation for each day of the year. The moving window of 30 days ( 15 days preceding the mark day and 14 days following the mark day) is used. 


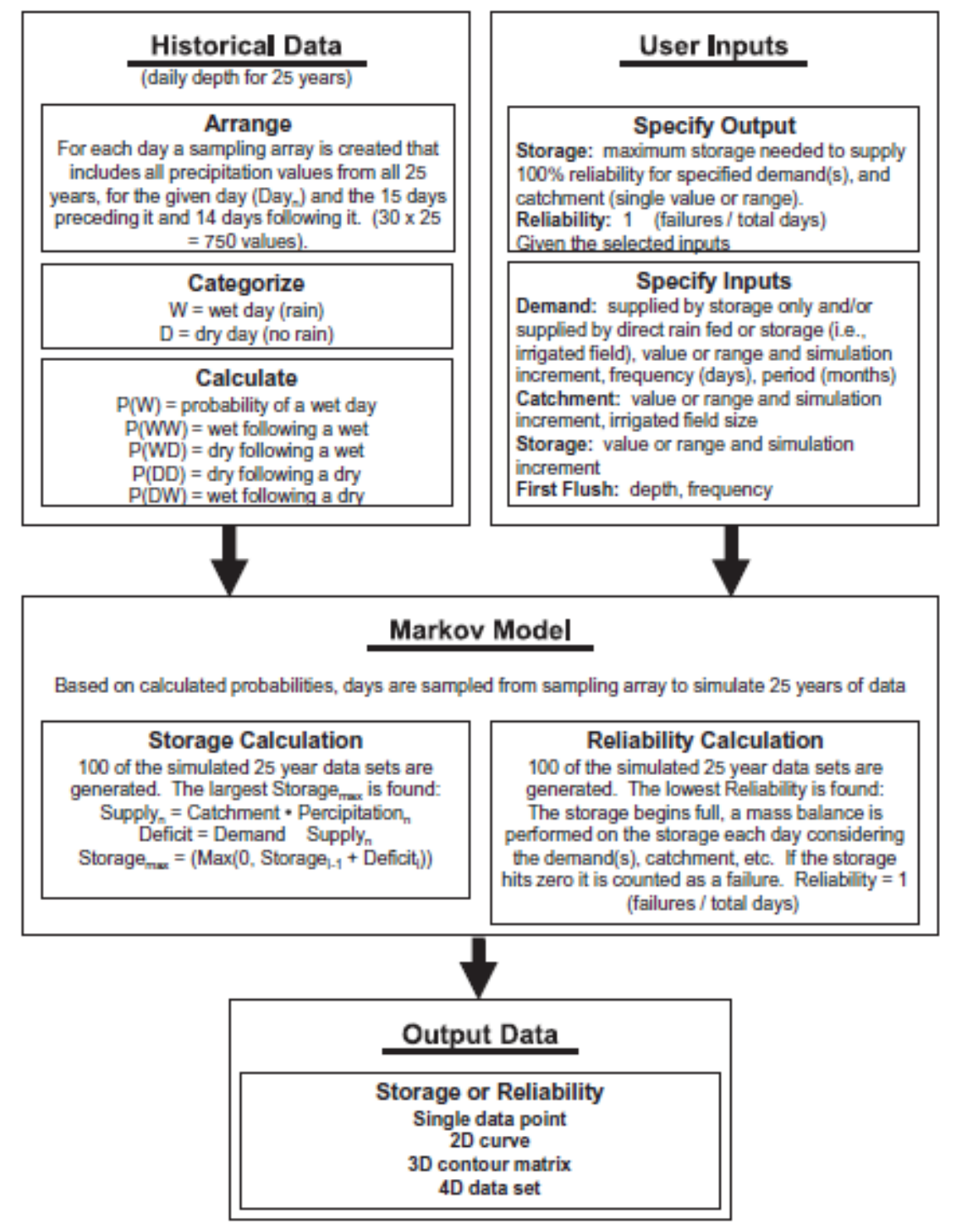

Figure 4. Schematic diagram of the Shortage and Reliability Estimation Tool (SARET) (M. Basinger et., al)

First order Markov chain probabilities for each day of the year is assigned as follows:

$$
\begin{aligned}
& P_{i}(W)=\frac{W}{W+D} \\
& P_{i}(W W)=\frac{W W}{W W+W D} \\
& P_{i}(W D)=1-P(W W) \\
& P_{i}(D D)=\frac{D D}{D D+D W} \\
& P_{i}(D W)=1-P(D D)
\end{aligned}
$$


Where $W=$ Number of wet days, $D=$ Number of dry days, $W W=$ Number of wet following wet days, $W D=$ Number of dry following wet days, $D D=$ Number of dry following dry days, $D W=$ Number of wet following dry days, $P_{i}(W)=$ Probability wet day at day "i". $P_{i}(W W)=$ Probability that day "i" will be wet given day " $\mathrm{i}-1$ " was wet, $\mathrm{P}_{\mathrm{i}}(\mathrm{WD})=$ Probability that day " $\mathrm{i}$ " will be dry given day " $\mathrm{i}-1$ " was wet, $\mathrm{P}_{\mathrm{i}}(\mathrm{DD})=$ Probability that day "i" will be dry given day "i-1" was dry, $\mathrm{P}_{\mathrm{i}}(\mathrm{DW})=$ Probability that day "i" will be wet given day "i-1" was dry.

It incorporates seasonal variation directly into rainfall generation. A synthetic series of 100 different wet and dry realizations are generated. When "wet/dry flags" are assigned to all days of simulated rainfall series actual precipitation amounts are then "sampled randomly (with replacement) from the moving window of daily precipitation observation corresponding to mark day.

Boot strapping technique is used to calculate the "reliability" of the RWH system with which tanks of different volume can meet various different demands a boot on the generated precipitation ensemble of 100 realizations. SARET can present output in four different ways (1) generate a single "reliability data point" for a given catchment area, storage volume and demand (irrigation area, depth and frequency), (2) generate a "reliability matrix" for a given demand with variable catchment areas and storage volumes, (3) generate a "reliability matrix" for a given catchment area, with variable demand and storage volume, (4) generate a "reliability dataset" for ranges for the demand, catchment area and storage volume to use in simulation. SARET uses simple mass balance as we discussed earlier to calculate the volume of storage for each day of each of the 100 different realization of the synthetic precipitation sequence.

SARET allows the user to specify a daily demand and also allows user to vary on a month-by-month basis. For irrigation purpose the demand is met with tank water only if there has not been enough precipitation to fulfil the irrigation demand.

\subsection{Portland case study}

The city of Portland is making efforts to educate people to install RWH systems in their houses to save potable water uses and also to reduce the load on combined sewers. For this study we are considering single family homes as our point of interest and use of harvested water for backyard/front yard irrigation. The first step in calculating the reliability of any RWH system is a reliable historical precipitation data. I collected 15 years of data for the city of Portland. I have considered my year from 
September 1 to August 31 (for example my year 1999 is from September 1, 1998 to August 31, 1999). Rainfall data is obtained from following website. The map of gages can be found in Appendix.

http://or.water.usgs.gov/non-usgs/bes/raingauge info/clickmap.html.

Although significant spatial differences can occur in particular precipitation event across Portland city but over longer time duration precipitation amounts recorded at gage stations distributed across the city are similar. A statistical analysis performed on 15 years of yearly precipitation amounts for 36 active gages across the city of Portland shows a standard deviation of $<10 \%$ annually. When there were missing data, they were assumed to be zero. Such an assumption implies more reliability and the potential for potable water saving may be higher than the figures obtained by running model. Annual precipitation averaged for 36 active gages is shown in figure 5. The average for the last fifteen years is 36.64 inches though annual total during some years drops to as low as 21 inches and rises up to as high as 55 inches. The standard deviation is about $25 \%$. No apparent upward or downward trends were detected.

Figures 6 and 7 represent daily and seasonal precipitation amount in Portland city over the last 15 years. A histogram of the daily precipitation totals across all days in the historical record is skewed toward left with $75 \%$ of days having precipitation amounts of 0.1 inches or less. Figure 7 is a box and whisker plot representing monthly total for 15 year records. The figure shows that there is a significant variability in the monthly rainfall amounts from year to year. The median rainfall for months of November, December and January is of range 5.5-6.6 inches compare to median rainfall for months of June to September is of range $0.23-1.08$. This clearly indicates wet and dry seasons for Portland.

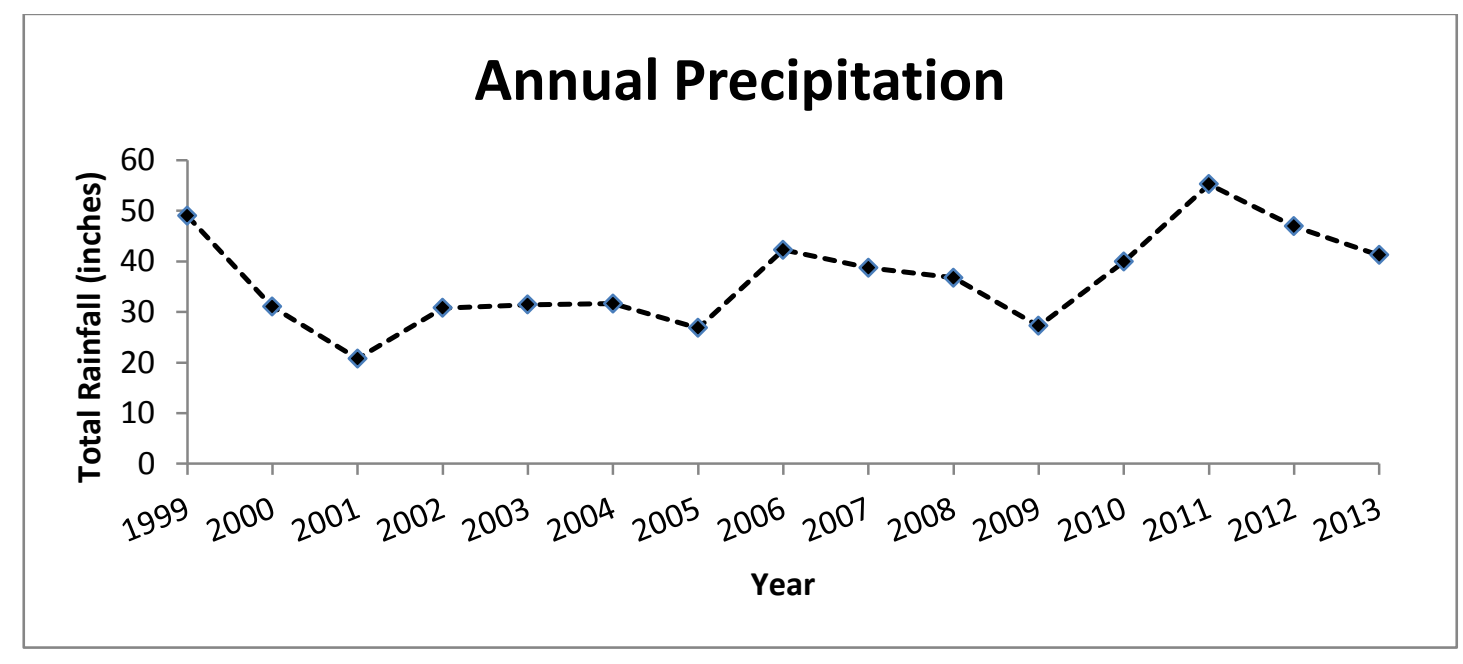

Figure 5. Annual Precipitation mean across city of Portland 


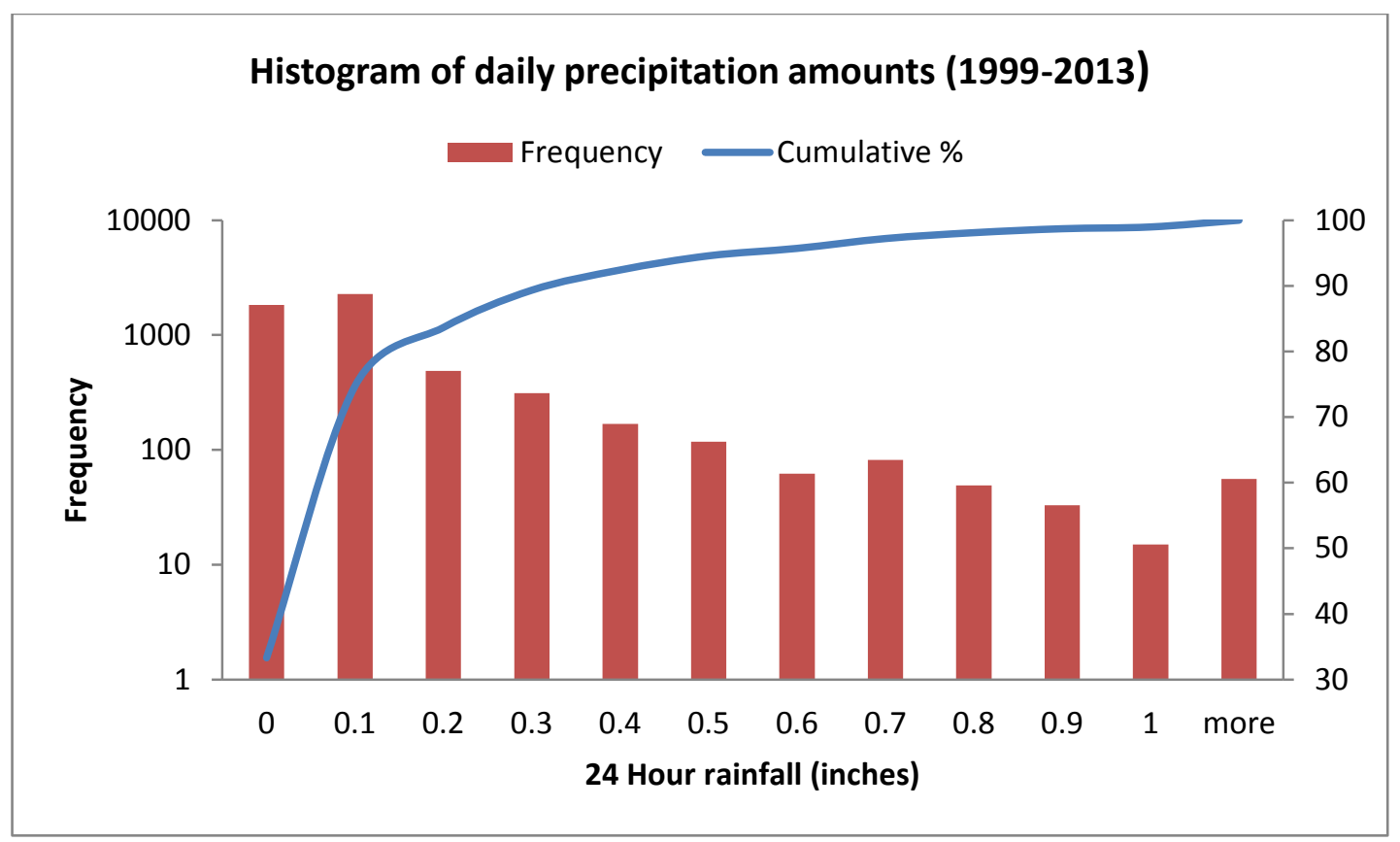

Figure 6. Histogram of daily precipitation amounts (1999-2013)

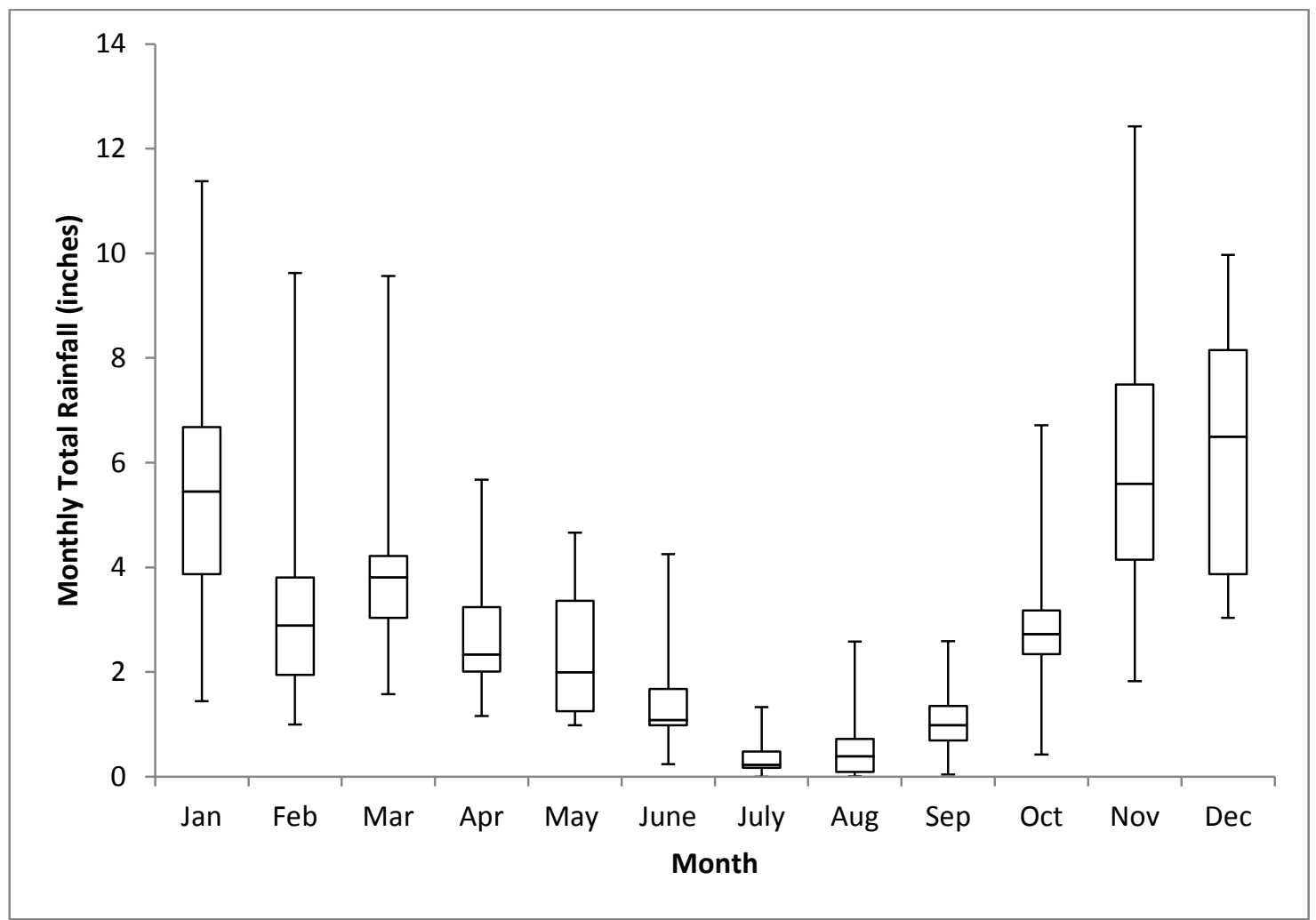

Figure 7. Box and Whisker plot depicting variability in monthly precipitation in Portland. The bottoms of the Whisker depict the lowest monthly value within 1.5 IQR of the lower quartile, and the highest Whiskers depict monthly values within 1.5 IQR of the upper 
Figure 8 represents the total rainfall (inches) in summer months which are also the months we need to irrigate our fields and also shows month by month distribution of rainfall (inches) from May - October from 1999-2013. This figure also confirms that July and August are the driest months so irrigation demand will be most in these months.

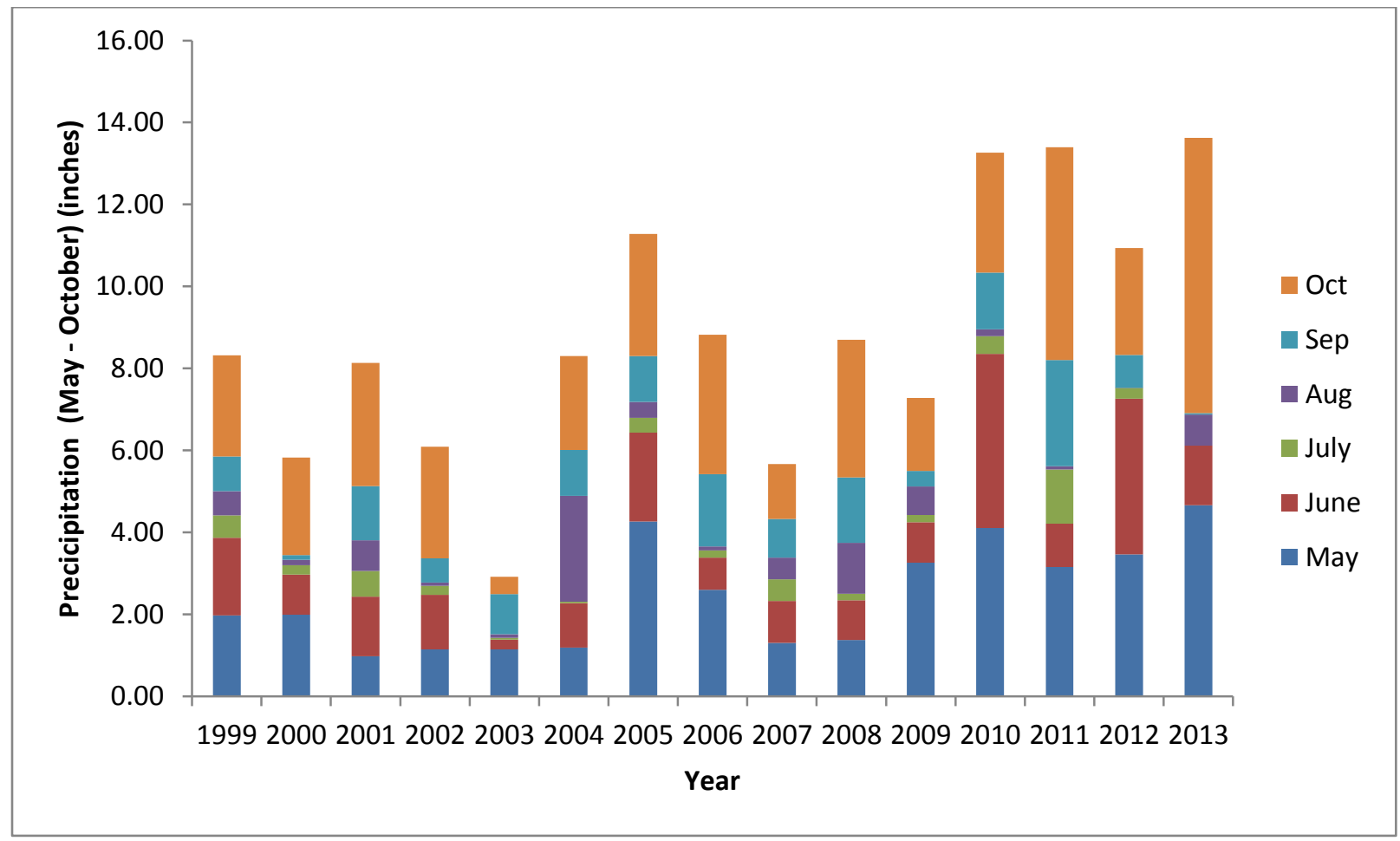

Figure. 8. Month wise distribution of precipitation (inches) from May - October (Summer Months) from 1999-2013

\subsection{Selection of Model parameters}

For this study we assume tank is covered, evaporation losses from the system as well as incident precipitation over the tank are neglected in the mass balance equation. We have assumed the run off coefficient as 1 and no quality aspects are taken into account which means we have not used the first flush diversion phenomenon.

\subsubsection{Range of roof area}

We have considered the roof area of $250 \mathrm{~m}^{2}$ for our historical water balance data model. And for the SARET we consider the buildings with footprint of $100-400 \mathrm{~m}^{2}$, a range that will include majority of roof area of the buildings found in Portland. 


\subsubsection{Range of storage tank volumes}

The range of available storage volume is assumed from 1 to $55 \mathrm{~m}^{3}$. The lower end of range is for rain barrels and upper end of range is for polyethylene tanks, installed above or below ground. We will also find the maximum storage required for given reliability. Determining an appropriate tank size is important/ crucial for establishing an effective rain water harvesting system.

\subsubsection{Irrigation Demand}

The demand is assumed to be only for irrigation purposes and incurred during the growing season only (May 1-October 31). The landscape area is assumed to be $100 \mathrm{~m}^{2}$ and we will assume water requirement per unit area from range $2 \mathrm{~cm} / 7$ days to $6 \mathrm{~cm} / 7$ days. The middle of the range which is $4 \mathrm{~cm} / 7$ days is used to calculate potable water saving and runoff reduction calculation. The demand is tank fed only if rainfall is not sufficient to meet the demand.

\section{RESULTS AND DISCUSSIONS}

\subsection{Maximum storage required (m3) for desired reliability}

As mentioned earlier we are calculating volumetric reliability per week for this study which is ratio of irrigation demand and water in the tank to fulfill that demand (if demand is $4 \mathrm{~m}^{3}$ and there is enough water in tank to fulfill it the ratio is 1 but if there is not enough water in tank, it has only $1 \mathrm{~m}^{3}$ then in this case reliability is $1 / 4=25 \%$ ).

Figure 9 is a plot between storage volume and different irrigation demand when we run model for all 15 years. It shows maximum storage volume required for a given irrigation demand to attain desired reliability (Percent). The catchment area $=250 \mathrm{~m}^{2}$, irrigation area $=100 \mathrm{~m}^{2}$ and irrigation demand varies. The storage volume required to attain $100 \%$ reliability with lower end of the demand is $27 \mathrm{~m}^{3}$ and with upper end of demand is $115 \mathrm{~m}^{3}$ which is practically not possible. Let us take closer look at this plot.

Figure 10 represents a closer look at the same plot. It can be seen that to obtain $50 \%$ reliability with any irrigation demand the storage volume required is less than $21 \mathrm{~m}^{3}$. If we assume irrigation demand as 
$4 \mathrm{~cm} / 7$ days the storage required to attain $50 \%$ reliability is $6.7 \mathrm{~m}^{3}$ which is more real world volume for single family house.

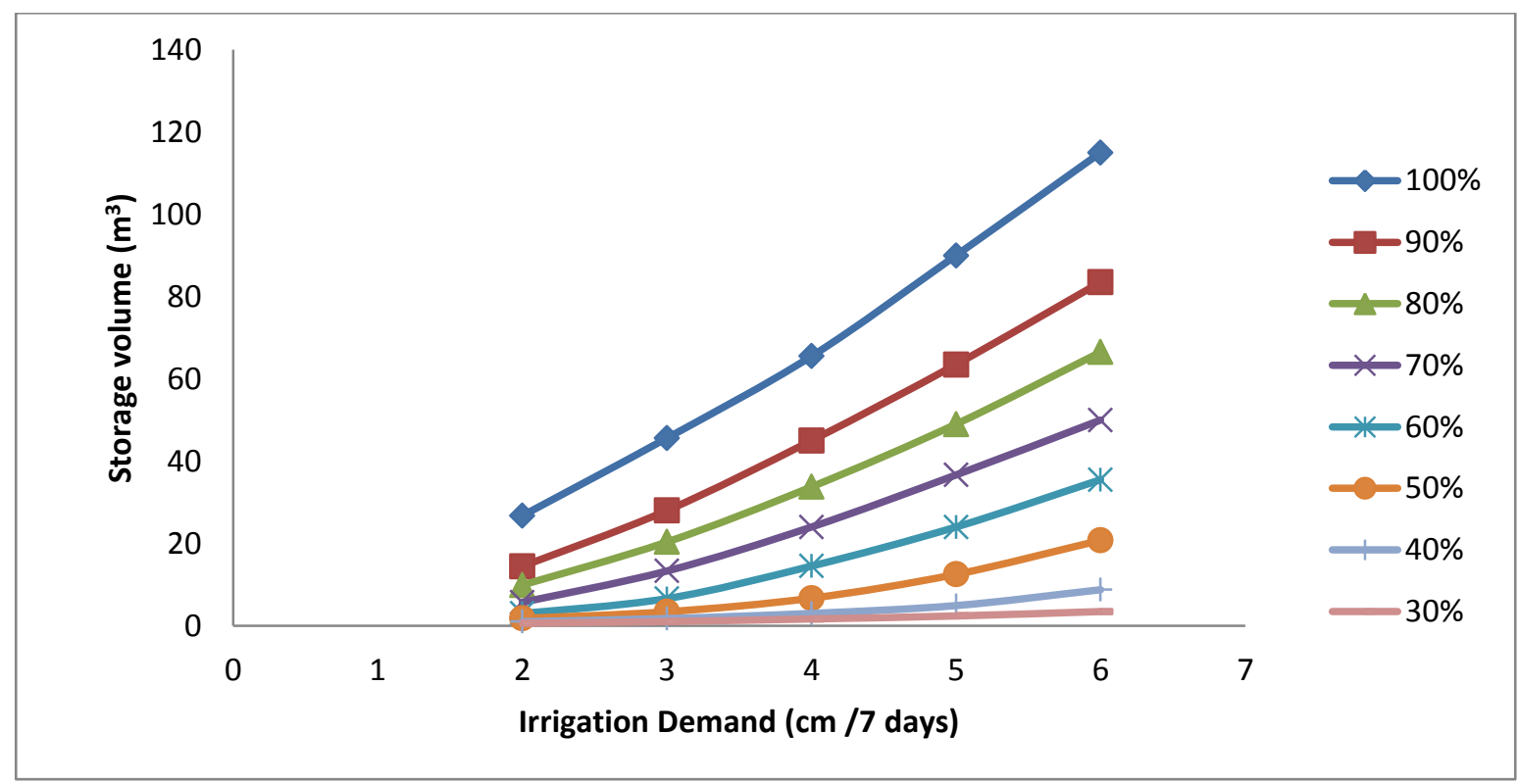

Figure.9. Plot Irrigation demand ( $\mathrm{cm} / 7$ days) versus storage volume $\left(\mathrm{m}^{3}\right)$ to achieve desired reliability when we run model for all 15 years. Irrigation area $=100 \mathrm{~m}^{2}$ and catchment area $=250 \mathrm{~m}^{2}$

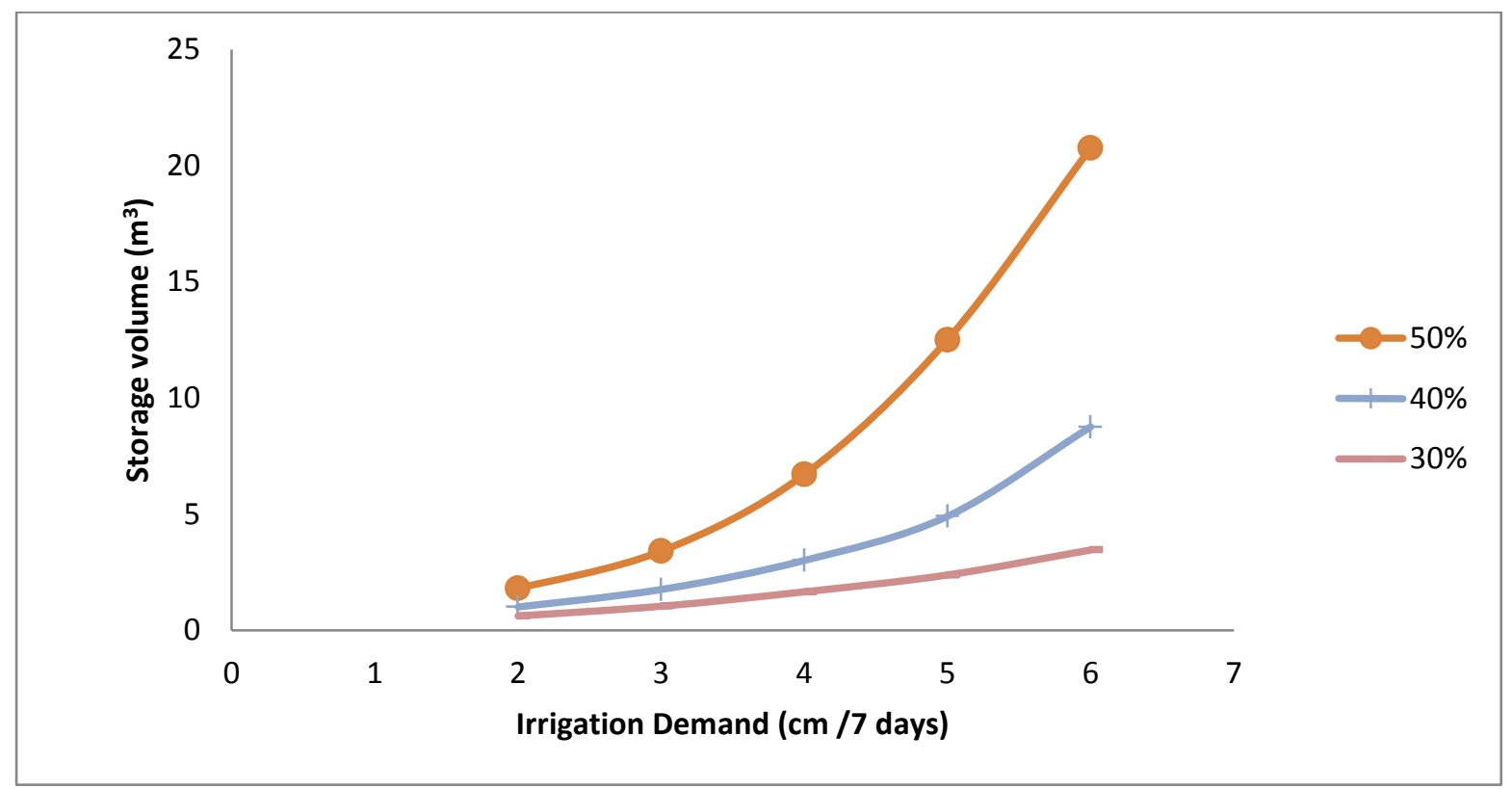

Figure.10. A zoomed look at figure 9 
Figure 11 and 12 represent the maximum volume of storage required to attain desired $20^{\text {th }}$ and $80^{\text {th }}$ percentile of reliability respectively. For $4 \mathrm{~m}^{3}$ of irrigation demand the average storage volume required to attain $40 \%$ reliability is $3 \mathrm{~m}^{3}$ whereas for $20^{\text {th }}$ percentile value it is $5.35 \mathrm{~m}^{3}$ and for $80^{\text {th }}$ percentile it is $1.75 \mathrm{~m}^{3}$. Another way to look at this is that with storage volume of $5.35 \mathrm{~m}^{3}, 20$ years out of hundred years the reliability will be equal to or less than $40 \%$ and with storage volume $1.75 \mathrm{~m}^{3}, 20$ years out of hundred years reliability will be equal to or more than $40 \%$.

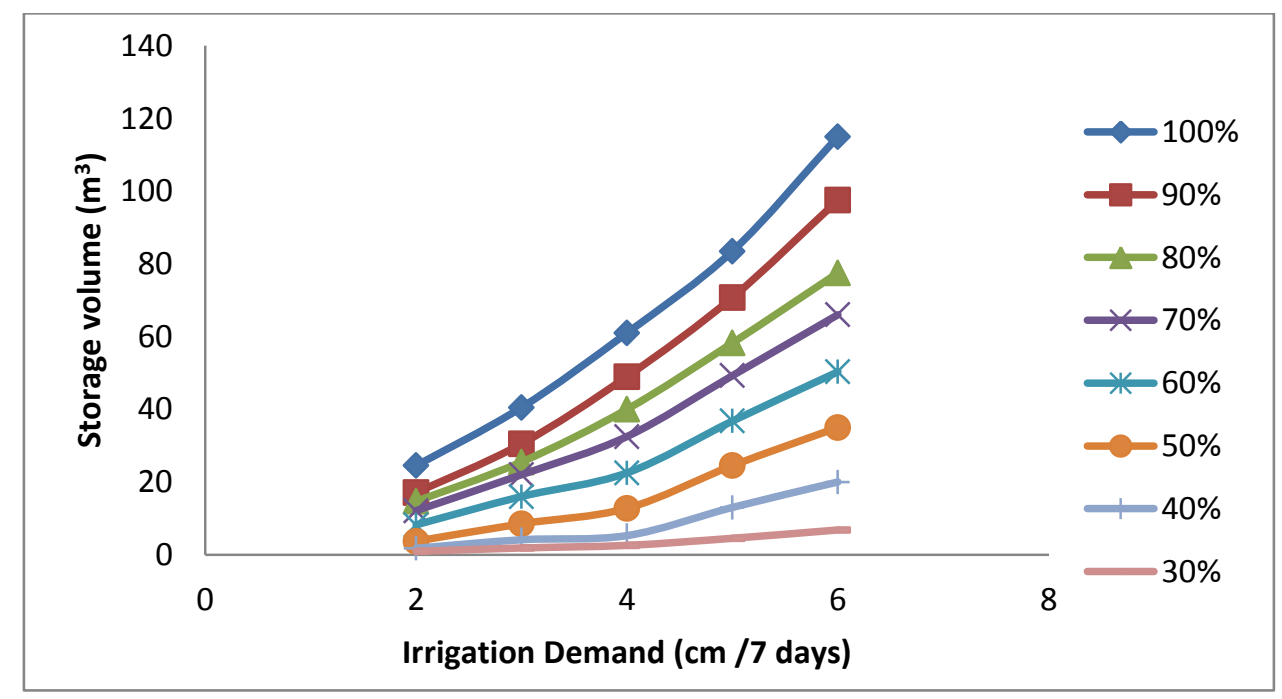

Figure.11. Plot Irrigation demand ( $\mathrm{cm} / 7$ days) versus storage volume $\left(\mathrm{m}^{3}\right)$ to achieve desired reliability $\left(20^{\text {th }}\right.$ percentile) when we run model for all 15 years. Irrigation area $=100 \mathrm{~m}^{2}$ and catchment area $=250 \mathrm{~m}^{2}$

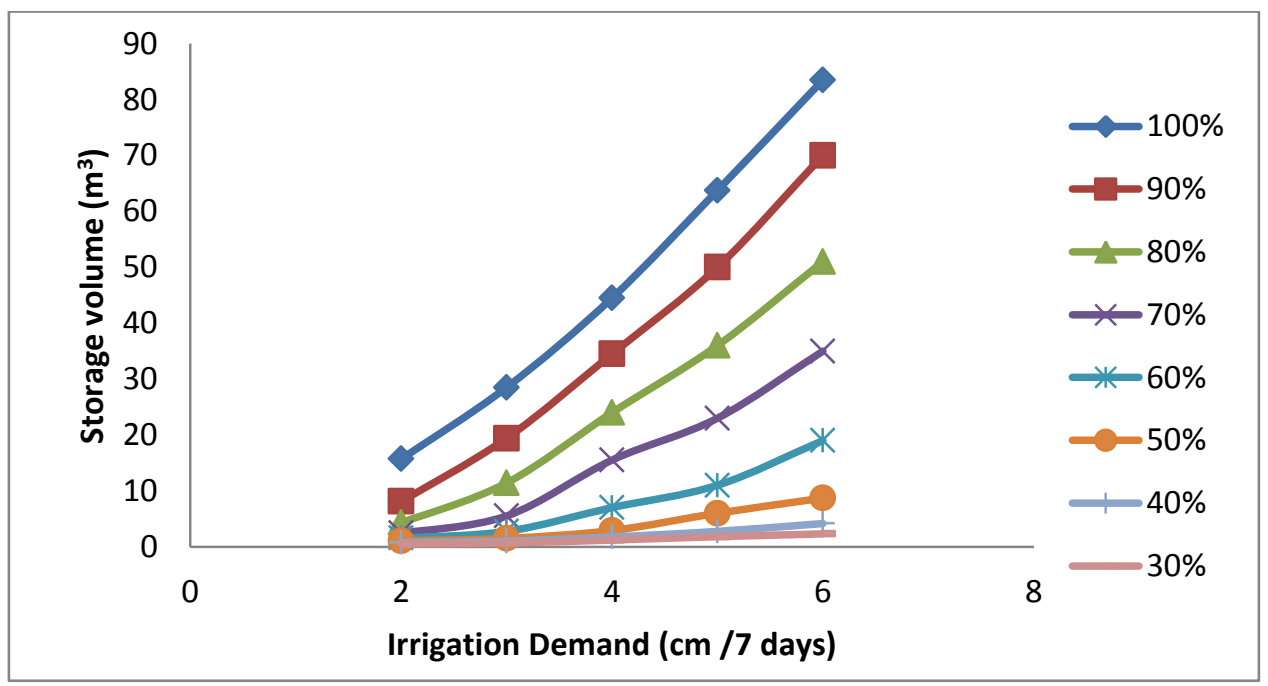

Figure.12. Plot Irrigation demand ( $\mathrm{cm} / 7$ days) versus storage volume $(\mathrm{m} 3)$ to achieve desired reliability (80th percentile) when we run model for all 15 years. Irrigation area $=100 \mathrm{~m} 2$ and catchment area $=250 \mathrm{~m} 2$ 


\subsection{Rain water harvesting system performance (Reliability)}

We are calculating reliability for two storage volumes so that we can compare the results and decide on the optimum storage volume. Figure 13 and 14 represent volumetric reliability (percent) each year with storage volume $=5 \mathrm{~m}^{3}$ and $10 \mathrm{~m}^{3}$ respectively, catchment area $=250 \mathrm{~m}^{2}$ and irrigation demand $=4 \mathrm{~m}^{3}$ $\left(100 \mathrm{~m}^{2}\right.$ irrigation area and water required $4 \mathrm{~cm}$ per 7 days). One thing to note here is that reliability is independent of the total rainfall for the year. However it partially depends on the rainfall in the months we are irrigating our fields. Total rainfall in the year 2006 is greater than the year 2005 but reliability calculated for the year 2005 is greater than the year 2006.Because the rainfall for months May-October (which are irrigation months) is more in 2005 than in 2006. Reliability is also a function of distribution of rainfall in these months. If the rainfall is more evenly distributed along all months it will have more reliability than in year when rainfall is not evenly distributed between months. For example in year 2005 the rainfall in summer months (May- October) is less but it is evenly distributed in comparison to year 2010 when rainfall is more in same months but it is not evenly distributed. As a result reliability in year 2005 is greater than reliability in year 2010 .

The reliability combine for all 15 years is $46 \%$ for $5 \mathrm{~m}^{3}$ storage volume and $55 \%$ for $10 \mathrm{~m}^{3}$ of storage volume. When we double the storage volume from $5 \mathrm{~m}^{3}$ to $10 \mathrm{~m}^{3}$ there is $22 \%$ rise in reliability. Further if we go on increasing our storage volume there will not be much change in reliability.

Figure 15 and 16 indicates the volume of water in the tank at any time between months May- October which are the months we are irrigating our gardens for storage volume $=5 \mathrm{~m}^{3}$ and $10 \mathrm{~m}^{3}$ respectively. For this plot we have averaged the rainfall for all 15 years to a single year. In fig 15 the volume of water reaches zero for the first time in approximately third week of June and after that it never reaches even to $3 \mathrm{~m}^{3}$. After first week of October it again starts to rise up and reaches its full capacity by mid of October. As predicted in July and August which are driest months there are no peaks, volume of water in storage barely rise to $1 \mathrm{~m}^{3}$ with one or two exceptions.

In figure 16 the volume of water reaches zero for the first time in second week of July compared to third week of June in figure 15. As in figure 15 here also water starts to rise up by first week of October and then never becomes zero and reaches its full capacity by mid of October. In July and August there is barely any water in the tank to irrigate the fields. The difference in reliability of the tank is mainly because as the volume is more it takes more time for $10 \mathrm{~m}^{3}$ tank to get empty in comparison to $5 \mathrm{~m}^{3}$ 
tank. As result we have more reliability in months of May and June. After that both tanks have approximately same volume of water in storage for the months of July, August, September and October.

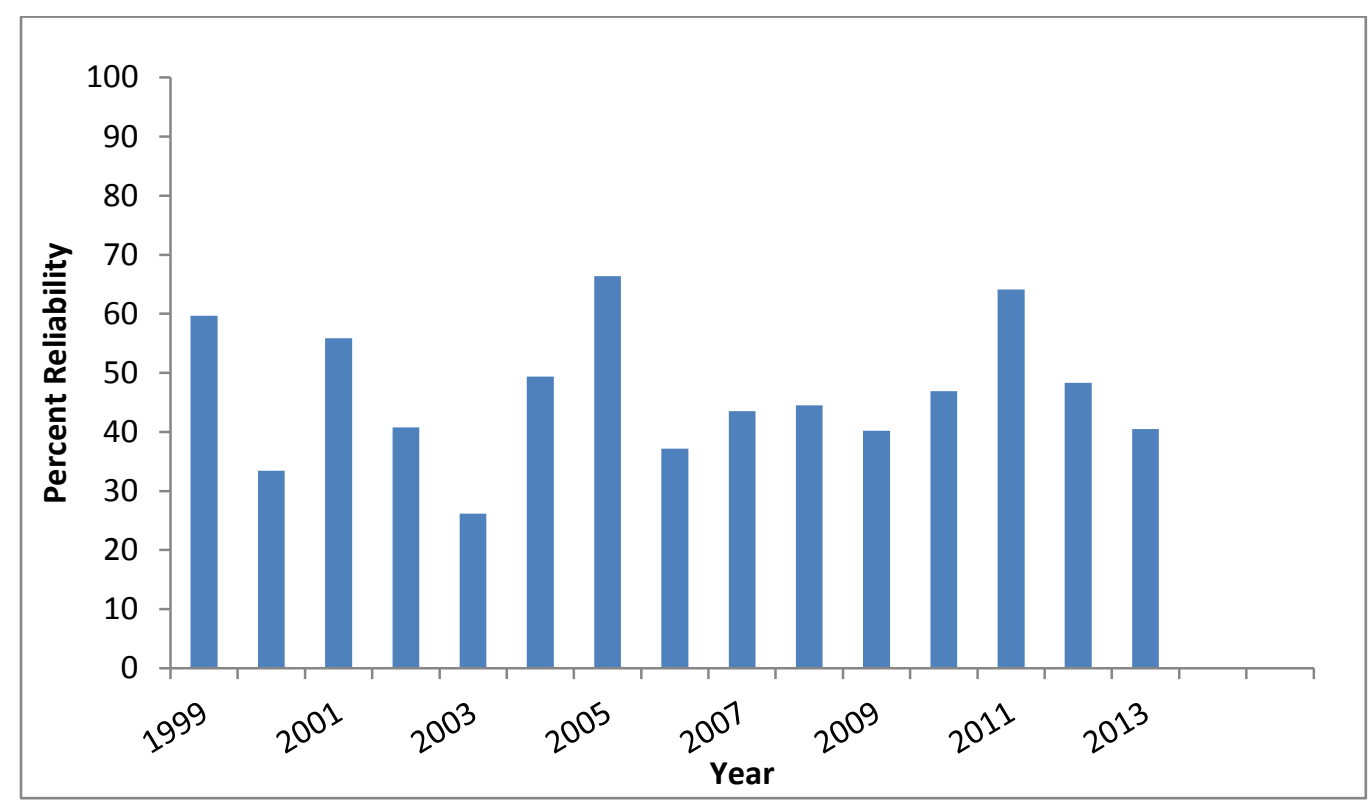

Figure.13. Percent reliability each year when $S m a x=5 \mathrm{~m}^{3}$, catchment area $=250 \mathrm{~m}^{2}$ and irrigation demand $4 \mathrm{~m}^{3} / 7$ days

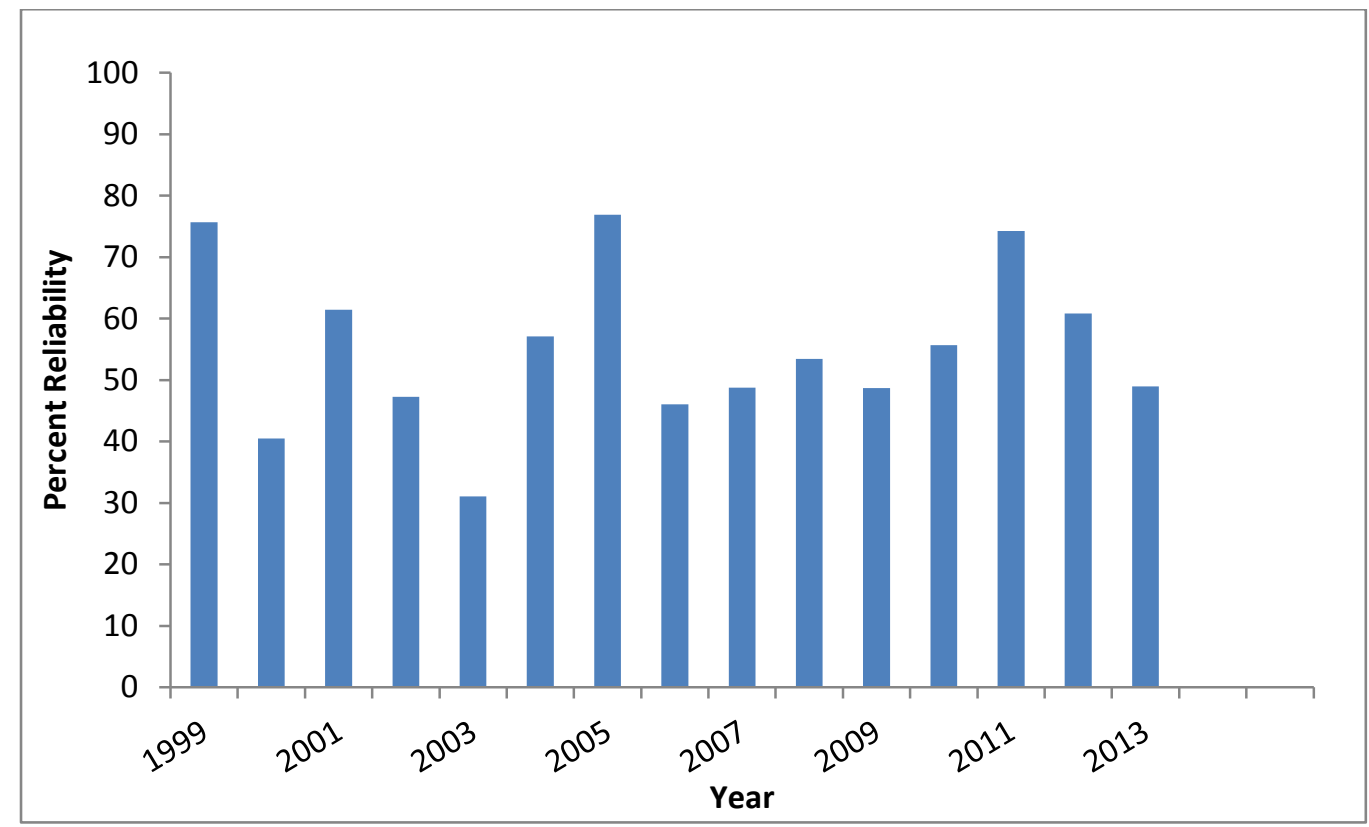

Figure.14. Percent reliability each year when $S \max =10 \mathrm{~m}^{3}$, catchment area $=250 \mathrm{~m}^{2}$ and irrigation demand $4 \mathrm{~m}^{3} / 7$ days 


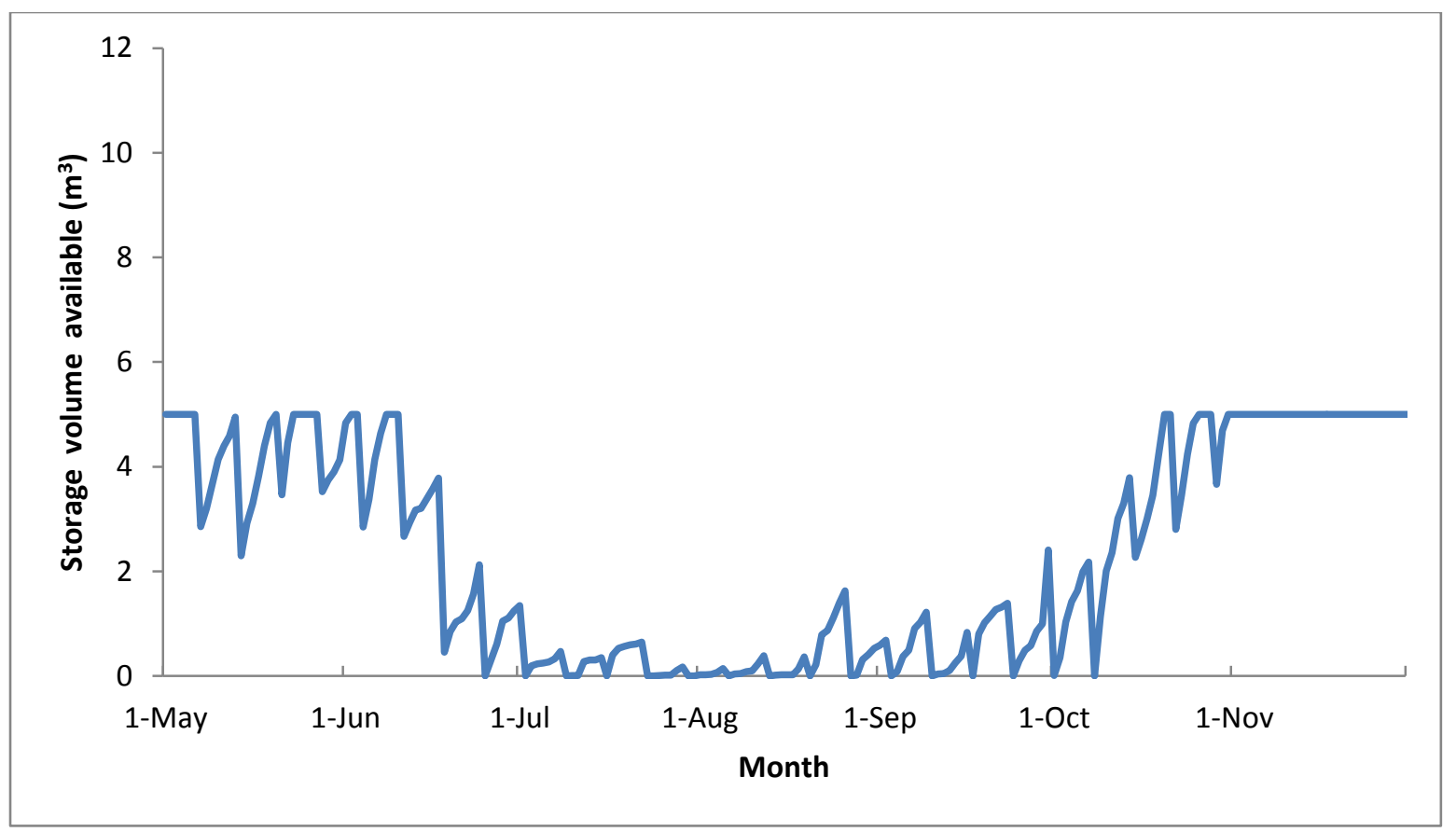

Figure.15. Storage volume available in summer months for $S \max =5 \mathrm{~m}^{3}$, catchment area $=250 \mathrm{~m}^{2}$ and Irrigation demand $=4 \mathrm{~m}^{3}$ per 7 days

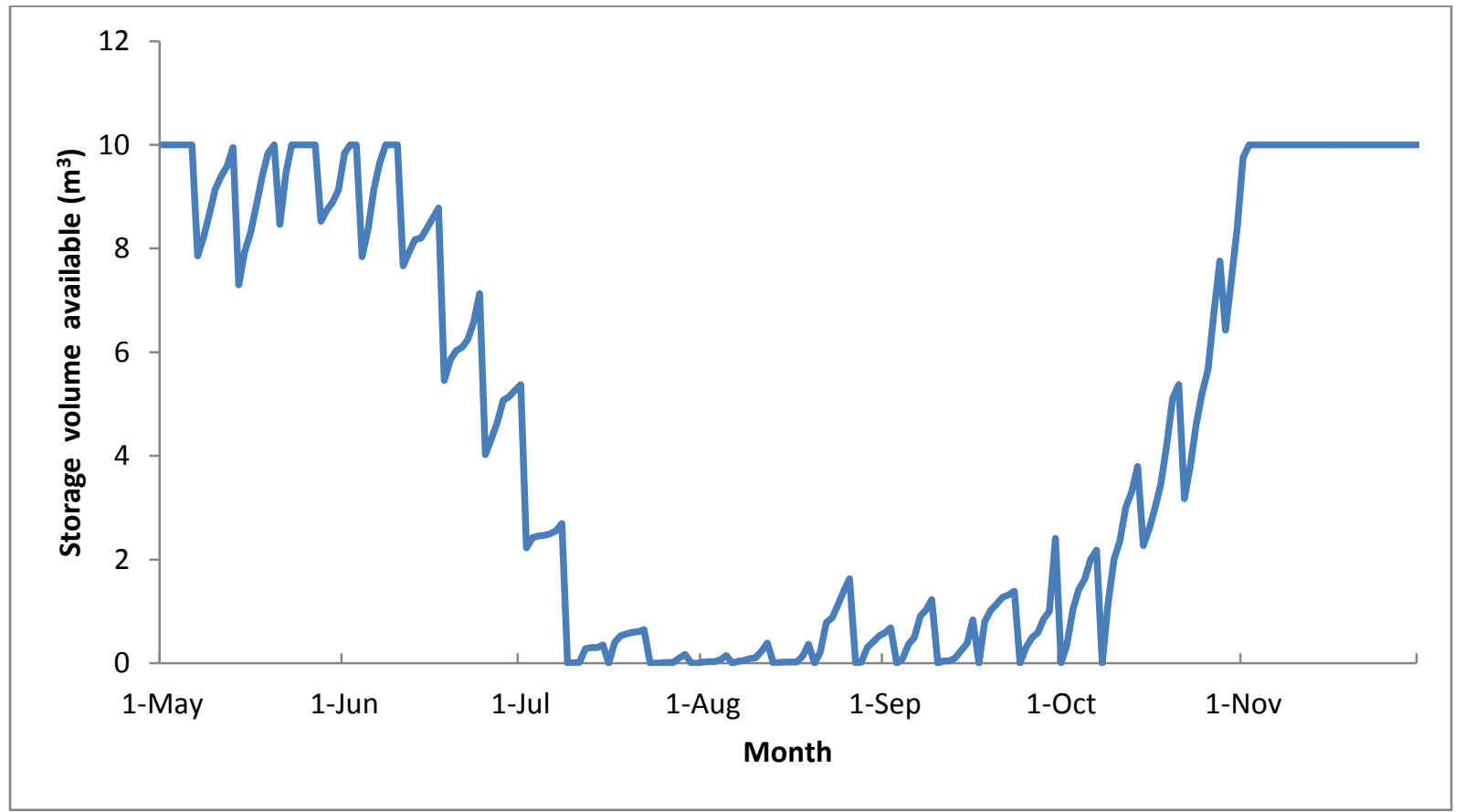

Figure.16. Storage volume available in summer months for $\operatorname{Smax}=10 \mathrm{~m}^{3}$, catchment area $=250 \mathrm{~m}^{2}$ and Irrigation demand $=4 \mathrm{~m}^{3}$ per 7 days 


\subsection{Volume of water required from city}

Figure 17 and 18 represent the volume of potable water required from city to meet the irrigation demand which is not fulfilled by rain water harvesting system for $S \max =5 \mathrm{~m}^{3}$ and $10 \mathrm{~m}^{3}$ respectively.

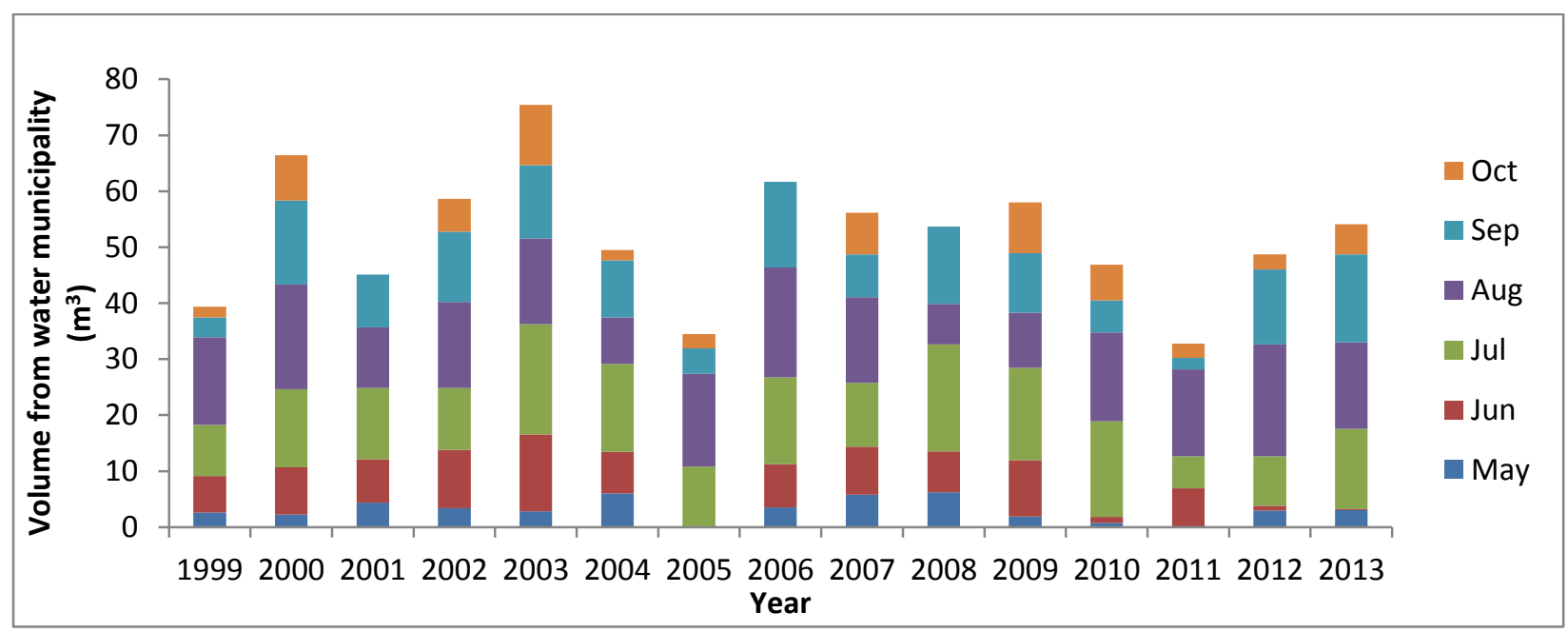

Figure.17. Volume of water required from municipality (month wise) in addition to water from rain water harvesting system with $\operatorname{Smax}=5 \mathrm{~m}^{3}$, catchment area $=250 \mathrm{~m}^{3}$ and Irrigation demand is $4 \mathrm{~m}^{3}$ per 7 days for last 15 years.

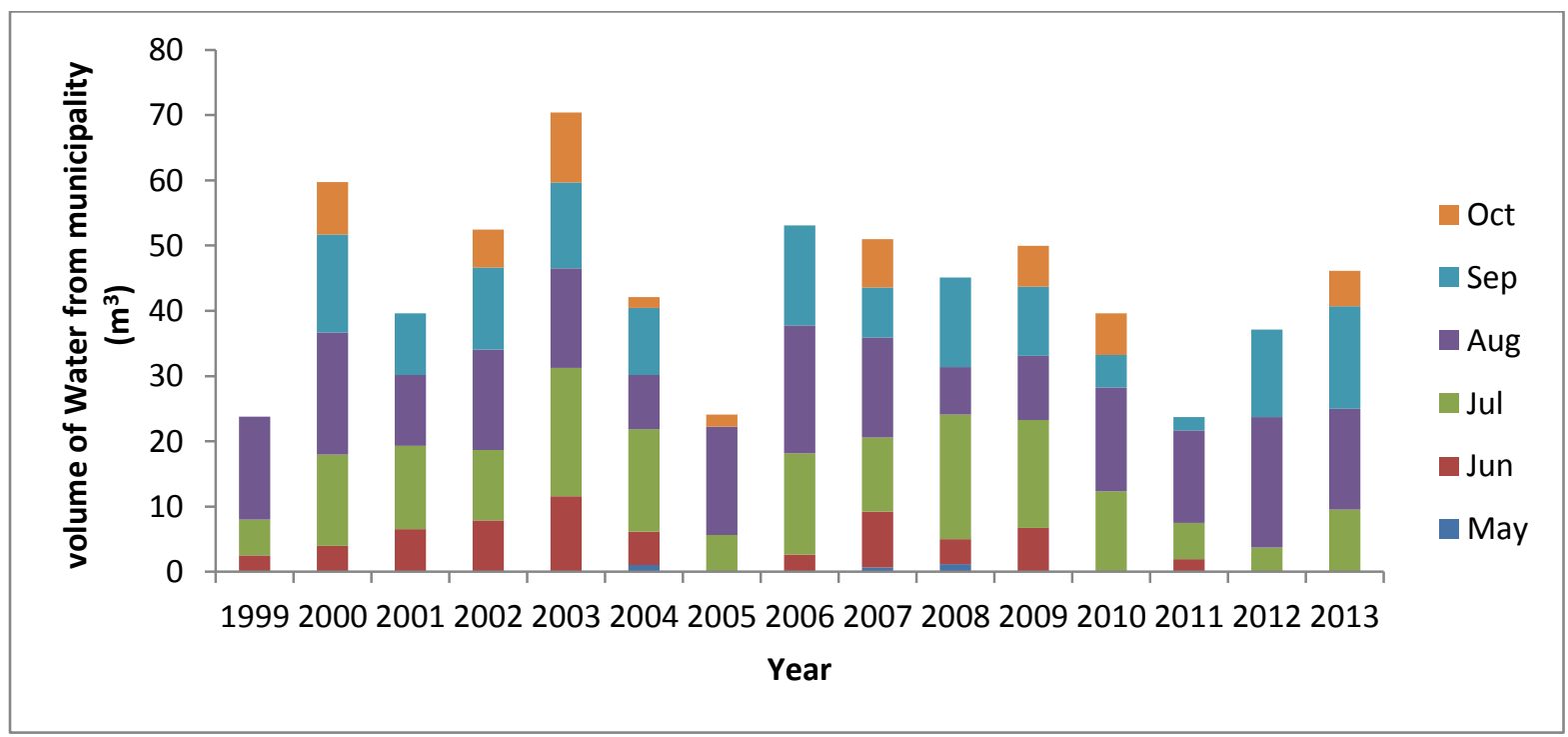

Figure.18. Volume of water required from municipality (month wise) in addition to water from rain water harvesting system with $S \max =10 \mathrm{~m}^{3}$, catchment area $=250 \mathrm{~m}^{2}$ and Irrigation demand is $4 \mathrm{~m}^{3}$ per 7 days for last 15 years. 
As predicted the volume of potable water required from city to meet the irrigation demand is related to rain water harvesting efficiency also known as reliability. In 2005 when reliability was high water required from city is less and in 2010 reliability is less so water required from city is more. The water required in months of July and August is more than any other month. Minimum water is required in the months of May and October. In figure 18 very less water is required from city in month of May in comparison to figure 17 . This as discussed is due to large storage capacity it takes time for $10 \mathrm{~m}^{3}$ tank to get empty and as result water required initially is less.

The volume of potable water required from city to fulfill irrigation demand which is not fulfilled by rain water harvesting system for all 15 years combine with $\operatorname{Smax}=5 \mathrm{~m}^{3}$ is $780 \mathrm{~m}^{3}$ and with $\operatorname{Smax}=10 \mathrm{~m}^{3}$ is $658 \mathrm{~m}^{3}$. Although the storage volume is double, volume of potable water required from city is $18 \%$ more with $\mathrm{Smax} 5 \mathrm{~m}^{3}$ than $\operatorname{Smax} 10 \mathrm{~m}^{3}$.

\subsection{Runoff reduction (Potable water saving)}

Figure 19 and 20 (Smax $=5 \mathrm{~m}^{3}$ and $10 \mathrm{~m}^{3}$ respectively) represent volume of run off saved from entering combined sewers with the help of rain water harvesting system. The water that is collected in the tank is the volume of water user prevented from entering into the sewer by installing rainwater harvesting system and that is equal to volume of water user will use to water their plants with. The volume of runoff/potable water saved depends on storage volume (Smax) with constant catmint area and irrigation demand as predicted. When Storage volume is more runoff/potable water saved is more and when storage is low runoff/potable water saved is less. But the percent increase decreases as we go on increasing the tank size.

The volume of runoff/potable water saved with $\mathrm{Smax}=5 \mathrm{~m}^{3}$ is approximately $490 \mathrm{~m}^{3}$ and with Smax $=$ $10 \mathrm{~m}^{3}$ is approximately $610 \mathrm{~m}^{3}$. The total precipitation for all past years (1999-2013) is approximately $13.96 \mathrm{~m}$ which when multiplied by catchment area $250 \mathrm{~m}^{2}$ gives total runoff if no rain water harvesting system in connected and that is equal to approximately $3500 \mathrm{~m}^{3}$. The percent runoff saved from entering combined sewers is approximately $15 \%$ and $17.5 \%$ for Smax $=5 \mathrm{~m}^{3}$ and $10 \mathrm{~m}^{3}$ respectively.

The saving in potable water is quite significant. Potable water saving ranges from $15 \%$ to $95 \%$, the lower end represents the tank volume as low as $1 \mathrm{~m}^{3}$ and upper and represents the tank volume as high as $60 \mathrm{~m}^{3}$. 


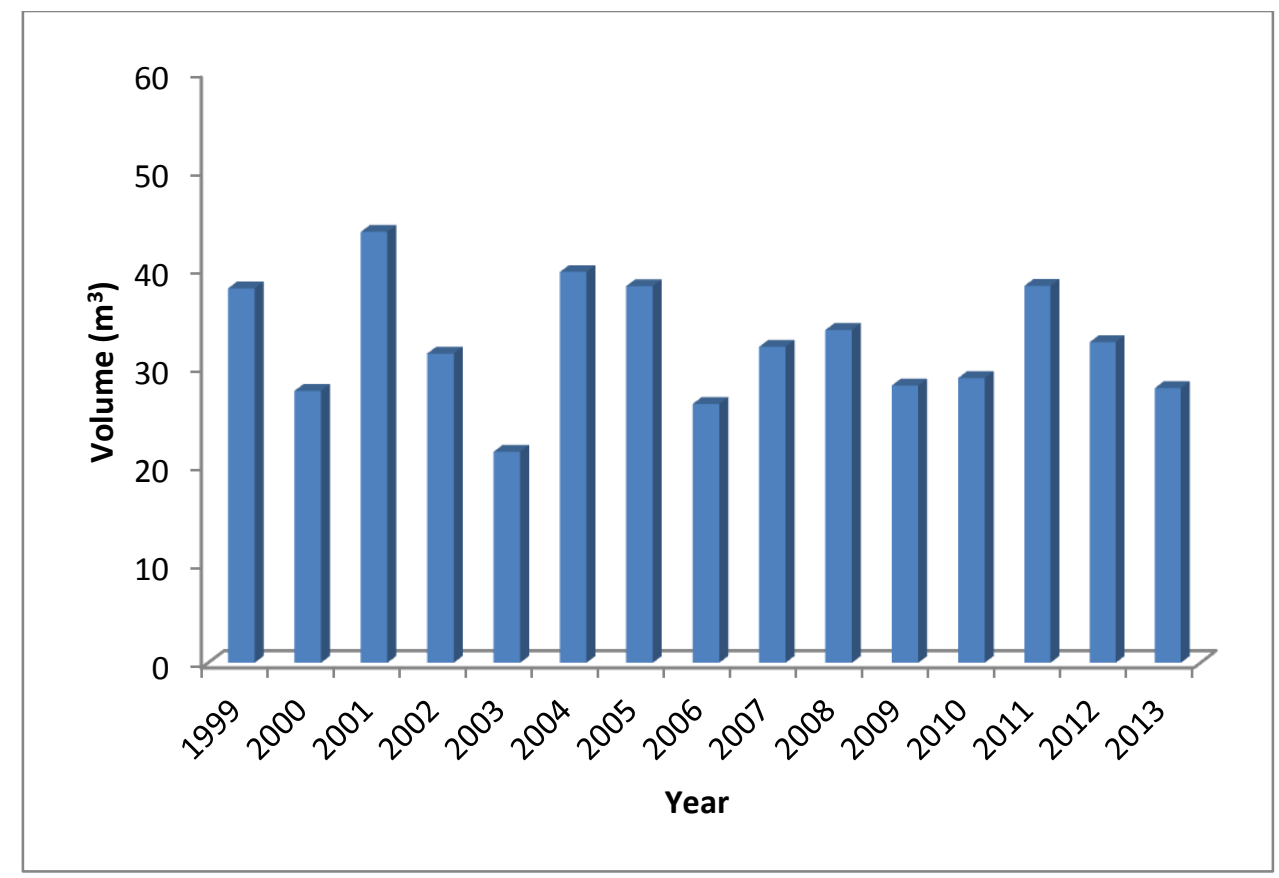

Figure.19. Runoff/potable water saved $\left(\mathrm{m}^{3}\right)$ each year by using rain water harvesting system with $\mathrm{Smax}=5 \mathrm{~m}^{3}$, irrigation demand $4 \mathrm{~m}^{3}$ per 7 days and catchment area $=250 \mathrm{~m}^{2}$.

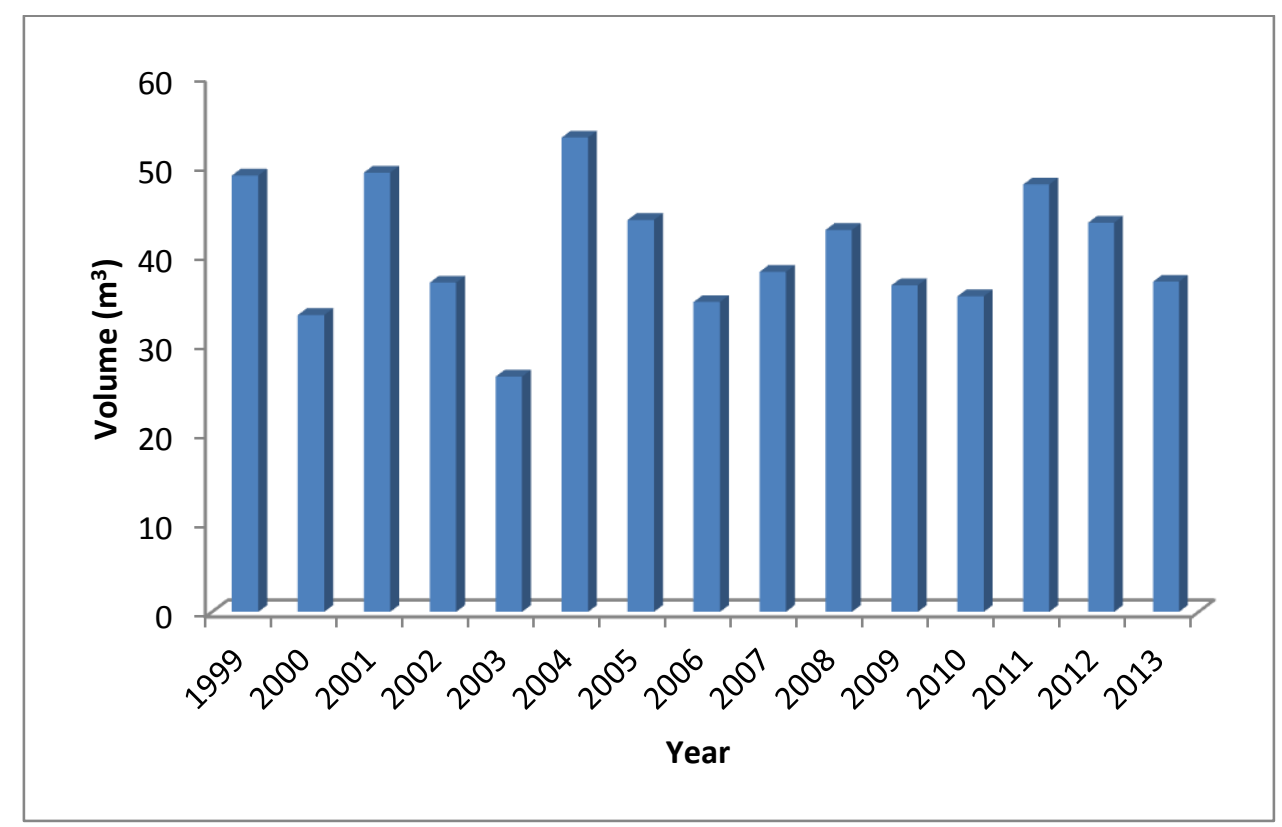

Figure.20. Runoff/potable water saved $\left(\mathrm{m}^{3}\right)$ each year by using rain water harvesting system with $\mathrm{Smax}=10 \mathrm{~m}^{3}$, irrigation demand $4 \mathrm{~m}^{3}$ per 7 days and catchment area $=250 \mathrm{~m}^{2}$ 


\subsection{Cost benefit analysis}

The cost of potable water for city of Portland is approximately 2.17 gallons per penny. For maximum storage volume $(\mathrm{Smax})=5 \mathrm{~m} 3$ the water saved is approximately $490 \mathrm{~m} 3$ which is approximately 130000 gallons and the savings in dollars for the past 15 years is approximately 600 dollars. And for maximum storage volume $(\mathrm{Smax})=10 \mathrm{~m} 3$ the water saved is approximately $610 \mathrm{~m} 3$ which is approximately 160000 gallons and the savings in dollar for the past 15 years is approximately 750 dollars. So by doubling the size of storage volume the water saved is not much and so is the dollar amount. The optimize tank size based on cost benefit analysis will be approximately $3-5 \mathrm{~m}^{3}$.

\subsection{Fill Time}

Figure 21 shows the number of days required to fill the storage volume given the catchment size. As expected the smaller storage volume with lower volume will fill within 20 days. It is assumed that tank will be empty with the start of November. So this fill time is based on when we start filling on November $1^{\text {st }}$ and tank is empty. The fill time is based on average rainfall year.

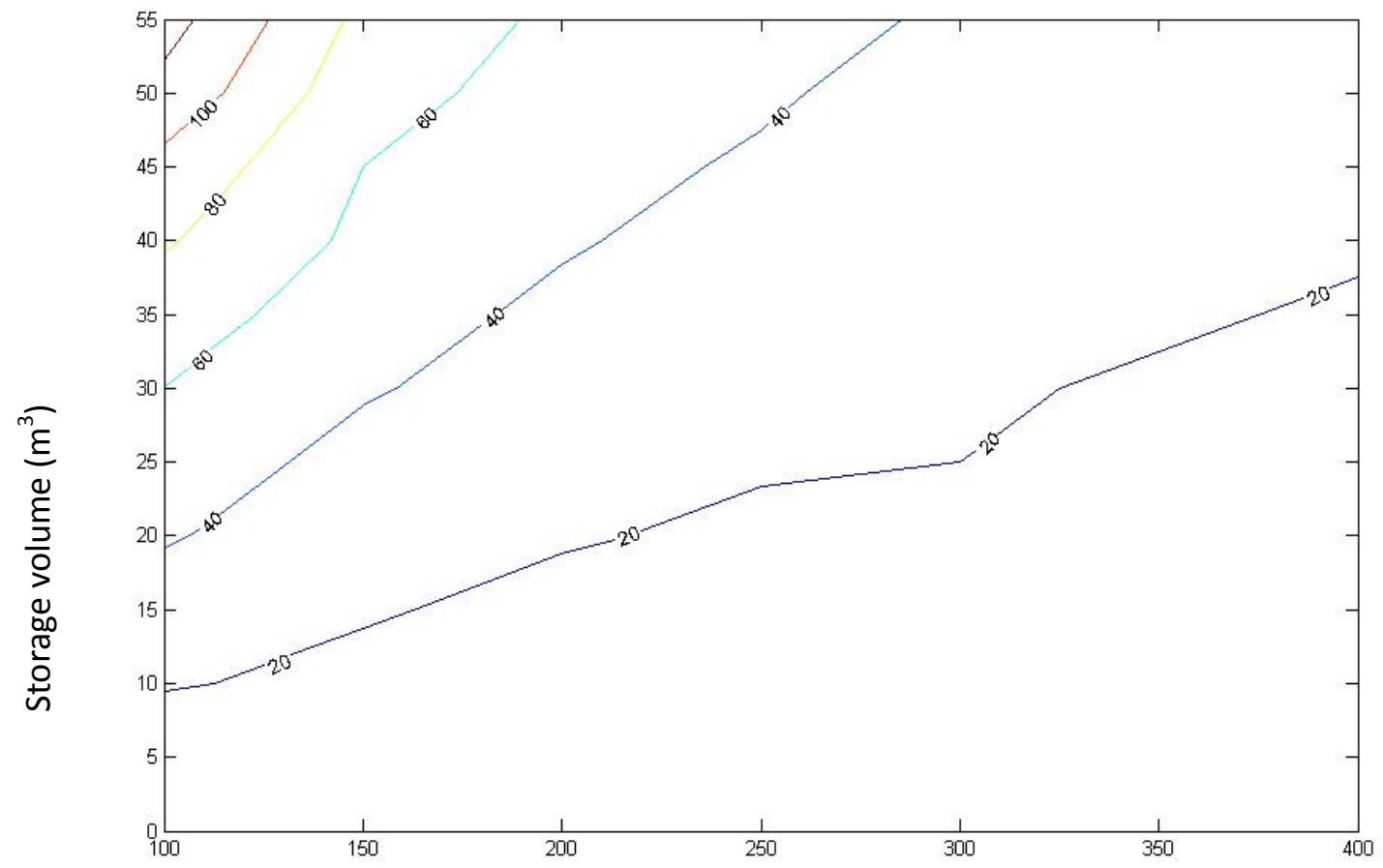

Catchment Area $\left(\mathrm{m}^{2}\right)$

Figure. 21. Time required to fill the storage volume from precipitation (days). 


\subsection{Discussion}

We discuss these results by comparing the results of historical water balance model to other models (SARET) of rainwater harvesting system reliability. A comprehensive study of SARET is done, as mentioned earlier we used this tool to generate contour plots of reliability. One problem was SARET uses time based reliability instead of volumetric reliability. In other words SARET counts the number of days during which the volume of stored water was insufficient to meet demand. These events are called failure and these events when divided by total number of days give rainwater harvesting system reliability. The reliability calculated based on this approach was very large. This is because irrigation demand is considered per week and SARET calculates reliability each day for example on day after irrigation demand is met the new irrigation demand is 0 and there is some water left in tank SARET calculates is as success and this is true for whole week(except the day we irrigate our plants). So to get the correct reliability changes are being made in the way the SARET calculates reliability. The results with volumetric reliability are shown in Figure 21.

The results obtained by this study are very similar to results obtained by SARET after making changes in reliability calculations. For a $5 \mathrm{~m}^{3}$ tank and for catchment area $250 \mathrm{~m}^{2}$ the percent reliability obtained is $46.5 \%$ with both the methods.

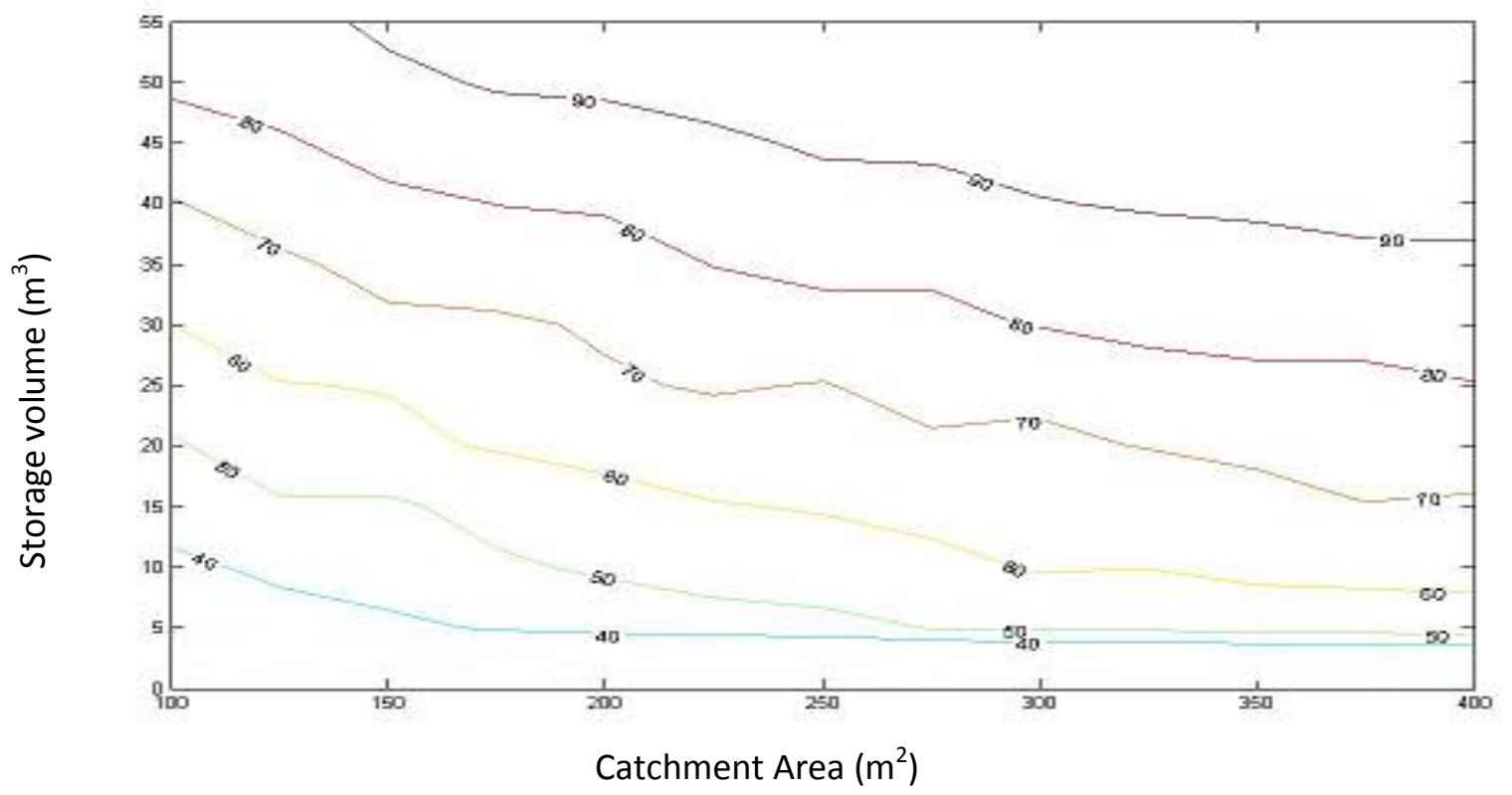

Figure. 22. Reliability contour for irrigation demand $4 \mathrm{~m}^{3} / 7$ days (May-October) 


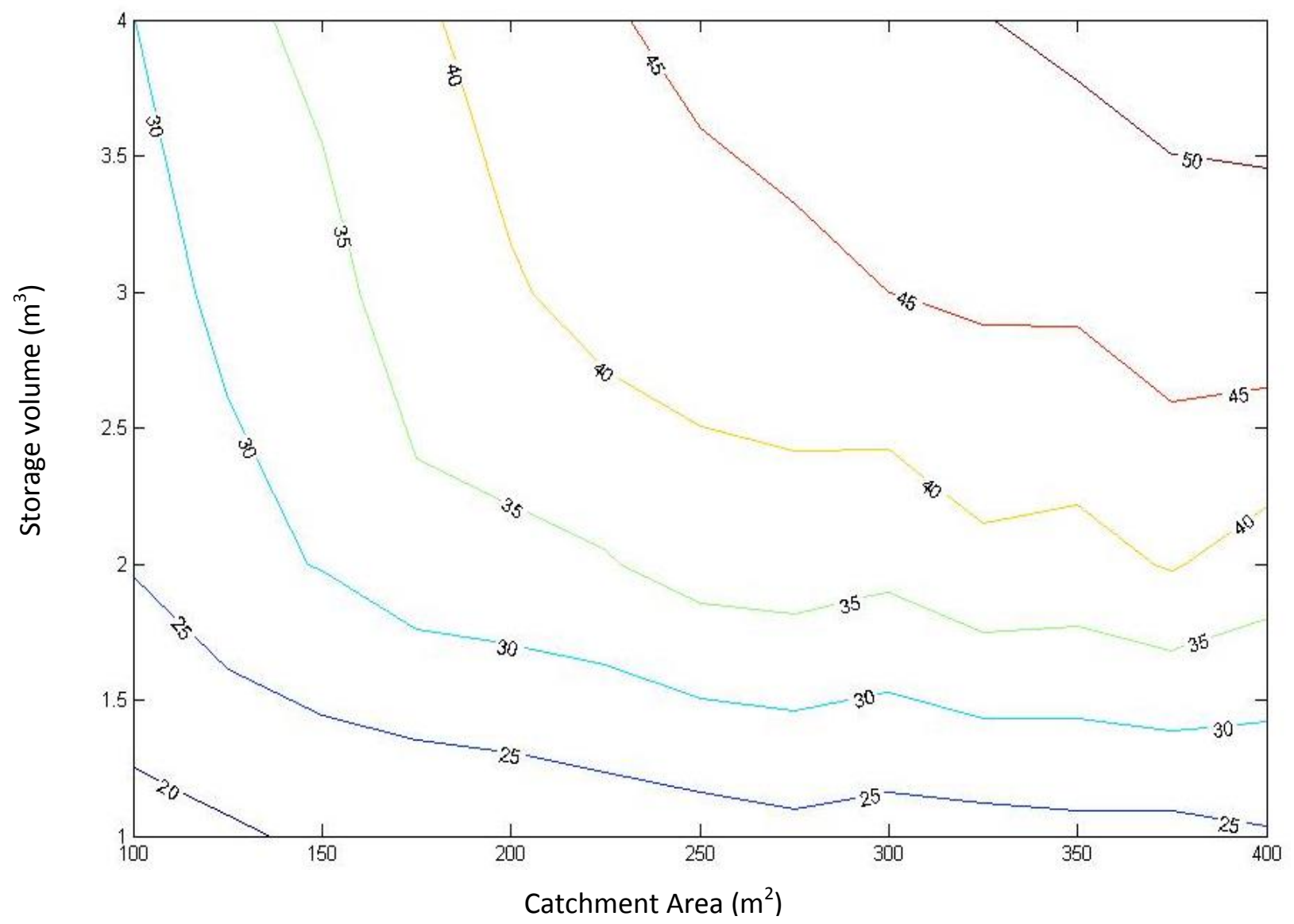

Figure. 23. Reliability contour for irrigation demand $4 \mathrm{~m}^{3} / 7$ days (May-October)

\section{CONCLUSION}

In this report we discussed the rainwater harvesting system reliability based on historical precipitation records for city of Portland. This is simple water balance approach for historical rainfall record which can be applied with any rainfall data and pattern.

To achieve $100 \%$ reliability the storage required is from $25 \mathrm{~m}^{3}$ to $115 \mathrm{~m}^{3}$. The lower value is for lower irrigation demand and higher value is for higher end of irrigation demand. To achieve $100 \%$ reliability is not a practical solution. A comparison of results from this study and results from SARET are similar. 
The runoff water saving for all years (when model is run for all 15 years) ranges from $5 \%$ to $35 \%$ for tank volume $1 \mathrm{~m}^{3}-60 \mathrm{~m}^{3}$ respectively and potable water saving ranges from $15 \%$ to $95 \%$. The lower end represents the tank volume as low as $1 \mathrm{~m}^{3}$ and upper and represents the tank volume as high as $60 \mathrm{~m}^{3}$.

The cost analysis is done for common public to give them a general idea and to make an educated decision about what size of rainwater harvesting system they should install to get maximum benefit. For tanks up to $5 \mathrm{~m}^{3}$ saving in water bills by saving municipal water from city are approximately same as the cost of installation of rainwater harvesting system. This means that with tank of size $5 \mathrm{~m}^{3}$ the money saved is approximately $\$ 600$ and the cost of installation of such system ( 250 gallon rain barrel cost $\$ 135$ on amazon) is also approximately $\$ 600$, so after 15 years of installation there will be actual savings. This study recommends the volume of storage tank for rainwater harvesting system for given demand, catchment area and irrigation area to be approximately $3-5 \mathrm{~m}^{3}$ to get maximum benefit.

For the city of Portland office there are two important benefits one benefit is per capita drinking water treatment cost is reduced and the other benefit is the stormwater runoff entering the combined sewers/river will be less.

This is just a preliminary study done specifically for the city of city of Portland to calculate the reliability of rainwater harvesting systems. This study is done considering only the irrigation demand and reliability with which demand can be met is calculated. Further research can be done for calculating reliability with which toilet flushing and combination of toilet flushing and irrigation demand can be met. The historical data used for this study is 15 years (1999-2013) by further increasing the length of historical data more precise results can be achieved. 


\section{REFERENCES}

http://or.water.usgs.gov/non-usgs/bes/raingauge info/clickmap.html.

http://www.portlandoregon.gov/water/article/278777

Agarwal, A., Narain, S., (1997). Dying Wisdom: The rise, Fall and Potential of India's Traditional Water Harvesting System. State of India's Environment 4, A citizen Report, CSE, New Delhi. 404p.

Basinger, M., Montalto, F., Lall, U., (2010). A rainwater harvesting system reliability model based on nonparametric stochastic rainfall generator. Journal of Hydrology 392, 105-118.

Evenri, M., (1961). Ancient Agriculture in Negev. Science 133, 976-986.

Gould, J., Nissen-Petersen, E., (1999). Rainwater Catchment Systems for Domestic Supply: Design, Construction and Implementation. Intermediate Technology Publication, London.

Ghisi, E., Bressan, D.L., Martini, M., (2007). Rainwater tank capacity and potential for potable water savings by using rainwater in the residential sector of southeastern Brazil. Building and Environment 42, 1654-1666.

Guo, Y., Baetz, BW., (2007). Sizing of rainwater storage units for green building applications. Journal of Hydrologic Engineering, 195-205.

Hasse, R., (1989). Rainwater Reservoir above Ground Structures for Roof zcatchment, Gate, Vieweg, Braunschweig/Wiesbaden, Germany, 102p.

Khastagir, A., (2010). Optimal sizing of rain water tanks for domestic water conservation. Journal of Hydrology 381, 181-188.

Palla, A., Gnecco, I., Lanza, L.G., (2011). Non-dimensional design parameters and performance assessment of rainwater harvesting systems. Journal of Hydrology 401, 65-76.

Radhakrishna, B.P., (2003). Rainwater harvesting, a time-honored practice: need for revival. Current science 85 (9), 1259-1261. 


\section{Appendix A}

\section{Portland gage map}

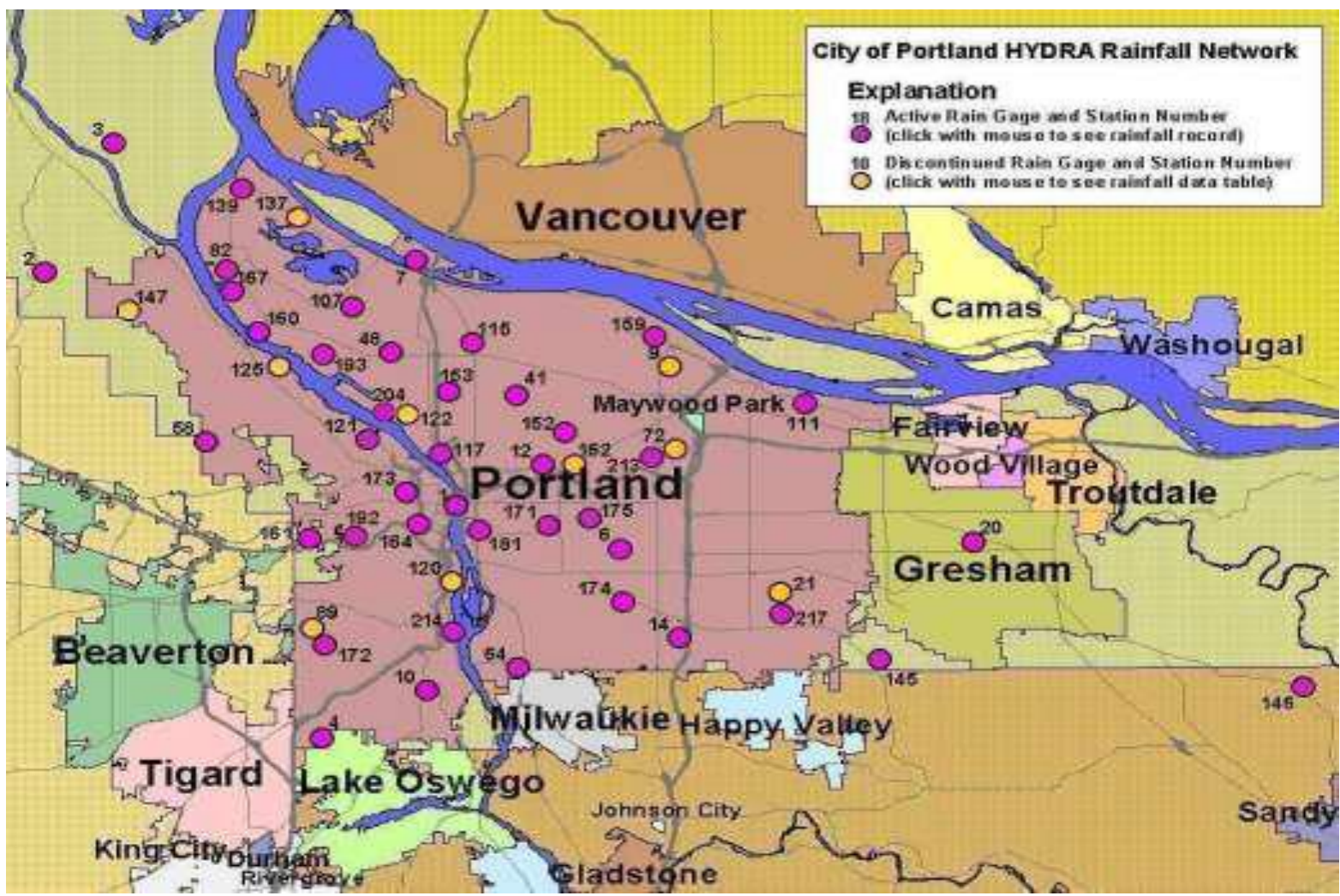

A list of all active gages is available at http://or.water.usgs.gov/non-usgs/bes/ 
